\title{
Cytotoxicity of ruthenium(II) piano-stool complexes with imidazole-based PN ligands
}

Huber, Wilhelm ; Broehler, Philip ; Waetjen, Wim ; Frank, Walter ; Spingler, Bernhard ; Kunz, Peter C

\begin{abstract}
A series of p-cymene ruthenium(II) complexes with imidazol-2-yl phosphines as PN ligands was prepared. Depending on the number of imidazolyl substituents in the ligands Ph3-nP(im)(n) 1-3: n = 1-3, im imidazol-2-yl (a), 1-methylimidazol-2-yl (b) different coordination modes were observed: kappa $\mathrm{P}$, kappa $\mathrm{N}-2, \mathrm{~N}$ or kappa $\mathrm{N}-3, \mathrm{~N}, \mathrm{~N}$. The complexes were tested for their cytotoxicity in different cancer cell lines. Most of the compounds were found to be non-toxic; The compounds (p-cymene)Ru(1a)Cl-2] (4a) shows cytotoxicity towards A2780sens and Hct116 cells in the mM range but not in H4IIE cells. The cytotoxicity is decreased upon introduction of a methyl group as (p-cymene) $\mathrm{Ru}(1 \mathrm{~b}) \mathrm{Cl}-2]$ (4b) shows only modest toxicities in the cell lines investigated. The kappa $\mathrm{P}$ compound (p-cymene) $\mathrm{Ru}(2 \mathrm{a}) \mathrm{Cl}-2]$ (5a) shows selective toxicity in H4IIE cells after $72 \mathrm{~h}$ whereas the kappa $\mathrm{N}-2, \mathrm{~N}$ compound (p-cymene) $\mathrm{Ru}(2 \mathrm{a})$ Cl] OTf (5a') showed no toxicity in the cell lines investigated which again. (C) 2012 Elsevier B. V. All rights reserved.
\end{abstract}

DOI: https://doi.org/10.1016/j.jorganchem.2012.06.027

Posted at the Zurich Open Repository and Archive, University of Zurich

ZORA URL: https://doi.org/10.5167/uzh-65332

Journal Article

Accepted Version

Originally published at:

Huber, Wilhelm; Broehler, Philip; Waetjen, Wim; Frank, Walter; Spingler, Bernhard; Kunz, Peter C (2012). Cytotoxicity of ruthenium(II) piano-stool complexes with imidazole-based PN ligands. Journal of Organometallic Chemistry, 717:187-194.

DOI: https://doi.org/10.1016/j.jorganchem.2012.06.027 


\title{
Cytotoxicity of Ruthenium(II) Piano-Stool Complexes with imidazole-based PN Ligands
}

Wilhelm Huber, ${ }^{b}$ Philip Bröhler, ${ }^{c}$ Wim Wätjen, ${ }^{c}$ Walter Frank ${ }^{b, \hat{f}}$ and Bernhard Spingler ${ }^{d, \dot{t}}$ and Peter C. Kunz, ${ }^{a, b^{*}}$

a Institut für Pharmazeutische und Medizinische Chemie, Heinrich-Heine-Universität, Universitätsstr. 1, D-40225 Düsseldorf, Tel.: +49 211 81-12873, Fax: +49 211 81-12287, Email: peter.kunz@uni-duesseldorf.de.

$b$ Institut für Anorganische Chemie und Strukturchemie, Heinrich-Heine-Universität, Universitätsstr. 1, D-40225 Düsseldorf.

c Universitätsklinikum Düsseldorf, Institut für Toxikologie, Heinrich-Heine-Universität, Universitätsstr. 1, D-40225 Düsseldorf.

$d$ University of Zürich, Institute of Inorganic Chemistry, Winterthurerstrasse 190, CH-8057 Zürich.

$\neq \mathrm{X}$-ray structure analysis.

\begin{abstract}
A series of $p$-cymene ruthenium(II) complexes with imidazol-2-yl phosphines as PN ligands was prepared. Depending on the number of imidazolyl substituents in the ligands $\mathrm{Ph}_{3-\mathrm{n}} \mathrm{P}(\mathrm{im})_{\mathrm{n}}$ $\{$ 1-3: $\mathrm{n}=1-3, \mathrm{im}=$ imidazol-2-yl (a), 1-methylimidazol-2-yl (b) $\}$ different coordination modes were observed: $\kappa P, \kappa^{2} N, N$ or $\kappa^{3} N, N, N$. The complexes were tested for their cytotoxicity in different cancer cell lines. Most of the compounds were found to be non-toxic; The compounds $\left[(p\right.$-cymene $\left.) \mathrm{Ru}(\mathbf{1 a}) \mathrm{Cl}_{2}\right]$ (4a) shows cytotoxicity towards A2780sens and Hct116 cells in the $\mu \mathrm{M}$ range but not in H4IIE cells. The cytotoxicity is decreased upon introduction of a methyl group as $\left[(p\right.$-cymene $\left.) \mathrm{Ru}(\mathbf{1 b}) \mathrm{Cl}_{2}\right](\mathbf{4 b})$ shows only modest toxicities in the cell lines investigated. The $\kappa P$ compound $\left[(p\right.$-cymene $\left.) \mathrm{Ru}(\mathbf{2 a}) \mathrm{Cl}_{2}\right](\mathbf{5 a})$ shows selective toxicity in H4IIE cells after 72 hours whereas the $\kappa^{2} N, N$ compound [(pcymene $) \mathrm{Ru}(\mathbf{2 a}) \mathrm{Cl}$ ]OTf (5a') showed no toxicity in the cell lines investigated which again.
\end{abstract}

\section{Keywords}

Arene Complexes, Cytotoxicity, Metal-based Drugs, PN Ligands, Ruthenium 


\section{Introduction}

Since the authorization of cisplatin in 1978, the interest in and development of metal-based drugs prospers consistently. Still, cisplatin, cis-[ $\left.\mathrm{Pt}\left(\mathrm{NH}_{3}\right)_{2} \mathrm{Cl}_{2}\right]$, and its analogs, especially oxaliplatin and carboplatin, are basic chemotherapeutics in combination therapy. ${ }^{[1-3]}$ The therapeutic effect of cisplatin is based on DNA platination which triggers apoptosis. ${ }^{[4]}$ The major draw-back for a successful chemotherapy by platinum-based drugs is acquired resistance towards the applied drug during the course of therapy. ${ }^{[5]}$ In order to circumvent those resistance mechanisms drugs, which address alternative cellular targets have to be developed. ${ }^{[6-8]}$

The most promising metallodrugs besides cisplatin analogues are ruthenium-based drugs. ${ }^{[9,10,10-13]}$ Compounds of $\mathrm{Ru}(\mathrm{II})$ and $\mathrm{Ru}(\mathrm{III})$ are able to overcome cisplatin resistance. Their cytotoxicity and antimetastatic properties are combined with low overall toxicity. ${ }^{[9,14-17]}$ Trans-[RuCl $4(\mathrm{dmso})(\mathrm{Im})] \mathrm{ImH}(\mathrm{NAMI}-\mathrm{A}$, where $\mathrm{Im}=$ imidazole) has completed phase I clinical trials. ${ }^{[18]}$ Interestingly, NAMI-A is more active against metastases than against primary tumours. ${ }^{[19]}$ Half-sandwich $\mathrm{Ru}(\mathrm{II})$ arene complexes of the type $\left[\left(\eta^{6}-\right.\right.$ arene) $\mathrm{Ru}(\mathrm{YZ})(\mathrm{X})$ ], where $\mathrm{YZ}$ is a bidentate chelating ligand and $\mathrm{X}$ is a good leaving group, show promising in vitro and in vivo anticancer activity. ${ }^{[16]}$ These compounds coordinate to guanine N7 of DNA, which can be complemented by intercalative binding of an extended arene, as well as specific hydrogen-bonding interactions. ${ }^{[20,21]}$ For example, increasing the size of the coordinated arene is accompanied by an increase in activity in human ovarian cancer cell lines ${ }^{[16]}$ and the nature of the chelating ligand $\mathrm{YZ}$ and leaving group $\mathrm{X}$ seems influence their kinetics and even can change their nucleobase selectivity. ${ }^{[22]}$ The RAPTA family of organometallic $\mathrm{Ru}(\mathrm{II})$ compounds contain the water-soluble phosphine ligand phosphaadamantane (pta) or derivatives thereof. Usually these compounds exhibit moderate in vitro activity, and some compounds show no activity in healthy cells up to millimolar concentrations. The pta compounds show little activity against primary tumours in vivo, although they exhibit some capacity to reduce lung metastases derived from a mammary carcinoma xenograft grown in mice. ${ }^{[23]}$ The cytotoxicity of $\left[\mathrm{Ru}\left(\eta^{6}-p\right.\right.$-cymene $) \mathrm{Cl}_{2}$ (pta) $]$, in EAC cells is thought to be mediated by mitochondrial and Jun-N (amino)-terminal kinase (JNK)-p53 pathways. ${ }^{[24]}$ For all Ru(II) compounds it is believed that in vivo, analogous to cisplatin, aquation of the chlorido complex is largely suppressed in intracellular fluids (with chloride concentrations are about $100 \mathrm{mM}$ ), whereas in the cell nucleus with a much lower chloride concentration (ca. $4 \mathrm{mM}$ ) the active aqua species forms. ${ }^{[25,26]}$ Although their 
mechanism of action is still largely unknown, there is some evidence that RAPTA compounds work on molecular targets other than DNA, ${ }^{[27-29]}$ implying a biochemical mode of action profoundly different from classical platinum anticancer drugs.

We are currently examining the use of imidazole-based PN ligands in biomedical applications ${ }^{[30-32]}$ as well as in catalysis ${ }^{[33,34]}$. Here we present coordination chemistry of these PN ligands towards $\left(\eta^{6}\right.$-cymene $) \mathrm{Ru}(\mathrm{II})$ and basic cytotoxicity studies in different cancer cell lines.

\section{Experimental Section}

The ligands $\mathrm{Ph}_{3-\mathrm{n}} \mathrm{P}(\mathrm{im})_{\mathrm{n}}\{\mathbf{1}-\mathbf{3}: \mathrm{n}=1-3$, im = imidazol-2-yl (a), 1-methylimidazol-2-yl (b) $\}$ and $\left[(\mathrm{cym}) \mathrm{Ru}(\kappa P-\mathbf{1 b}) \mathrm{Cl}_{2}\right]$ (4b) were prepared according published procedures. ${ }^{[32,34-37]}$ All reactions were carried out in Schlenk tubes under an atmosphere of dry nitrogen using anhydrous solvents purified according to standard procedures. All chemicals were purchased from commercial sources and used as received. ${ }^{1} \mathrm{H}$ and ${ }^{31} \mathrm{P}$ NMR spectra were recorded on a Bruker DRX 200 and Bruker DRX 500 spectrometer. The ${ }^{1} \mathrm{H}$ spectra were calibrated against the residual proton signal of the solvent as an internal reference (methanol- $d_{4}: \delta_{\mathrm{H}}=3.31 \mathrm{ppm}$; $\left.\mathrm{D}_{2} \mathrm{O}: \delta_{\mathrm{H}}=4.79 \mathrm{ppm}, \mathrm{CDCl}_{3}: \delta_{\mathrm{H}}=7.26 \mathrm{ppm}\right)$ while the ${ }^{31} \mathrm{P}\left\{{ }^{1} \mathrm{H}\right\}$ NMR spectra were referenced to external $85 \% \mathrm{H}_{3} \mathrm{PO}_{4}$. The MALDI mass spectra were recorded on a Bruker Ultraflex MALDI-TOF mass spectrometer. The elemental composition of the compounds was determined with a PerkinElmer Analysator 2400 at the Institut fu $\square \mathrm{r}$ Pharmazeutische und Medizinische Chemie, Heinrich-Heine-Universita $\square \mathrm{t}$ Du $\square$ sseldorf.

\subsection{Synthesis of (cym)Ru-complexes}

\subsection{1 [(cym)Ru(кP-1a) $\left.\mathrm{Cl}_{2}\right](\mathbf{4 a})$}

Ligand 1a $(83 \mathrm{mg}, 0.33 \mathrm{mmol})$ and $\left[\mathrm{Ru}(\mathrm{cym}) \mathrm{Cl}_{2}\right]_{2}(100 \mathrm{mg}, 0.16 \mathrm{mmol})$ were dissolved in dry $\mathrm{CH}_{2} \mathrm{Cl}_{2}(15 \mathrm{~mL})$ and stirred for 24 hours. The dark red solution was concentrated to $5 \mathrm{~mL}$ and $\mathrm{Et}_{2} \mathrm{O}$ was added. The precipitate was collected and dissolved in thf, filtered and again precipitated upon addition of $n$-hexane. The red solid was filtered off and dried in vacuo. Yield: $52 \mathrm{mg}(28 \%) .{ }^{1} \mathrm{H}-\mathrm{NMR}\left(200 \mathrm{MHz}\right.$, methanol- $\left.d_{4}\right): \delta=0.97(\mathrm{~d}, J=7.0 \mathrm{~Hz}, 6 \mathrm{H}), 1.83$ (s, 3H), 2.42 (sept., $J=7.0 \mathrm{~Hz}, 1 \mathrm{H}), 5.42(\mathrm{~m}, 4 \mathrm{H}), 7.10$ (d, $J=1.2 \mathrm{~Hz}, 2 \mathrm{H}), 7.72(\mathrm{~m}, 10 \mathrm{H})$. ${ }^{31} \mathrm{P}\left\{{ }^{1} \mathrm{H}\right\}$-NMR (81 MHz, methanol- $\left.d_{4}\right): \delta=22(\mathrm{~s})$. EI-MS $\left(\mathrm{CH}_{3} \mathrm{OH}\right): \mathrm{m} / \mathrm{z}(\%)=558(40)$ $[\mathrm{M}]^{+}, 523(28)[\mathrm{M}-\mathrm{Cl}]^{+}, 486(100)[\mathrm{M}-2 \mathrm{Cl}]^{+}, 389(27)\left[\mathrm{M}-\mathrm{C}_{10} \mathrm{H}_{14}\right]^{+}, 352(45)\left[\mathrm{M}-\mathrm{C}_{10} \mathrm{H}_{14}-\mathrm{Cl}\right]^{+}$. $\mathrm{C}_{25} \mathrm{H}_{27} \mathrm{Cl}_{2} \mathrm{~N}_{2} \mathrm{PRu}$ (558.45): calc. C 53.77, $\mathrm{H}$ 4.87, N 5.02; found C 53.44, H 4.98, N 4.77. 


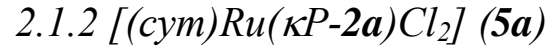

Ligand 2a (50 mg, $0.21 \mathrm{mmol})$ and $\left[\mathrm{Ru}(\mathrm{cym}) \mathrm{Cl}_{2}\right]_{2}(63 \mathrm{mg}, 0.1 \mathrm{mmol})$ were dissolved in dry $\mathrm{CH}_{3} \mathrm{CN}(25 \mathrm{~mL})$ and stirred for 24 hours. The dark red solution was concentrated to $5 \mathrm{~mL}$. The red precipitate was filtered off, washed with $\mathrm{Et}_{2} \mathrm{O}$ and dried in vacuo. Yield: $27 \mathrm{mg}$ (24 \%). ${ }^{1} \mathrm{H}-\mathrm{NMR}\left(200 \mathrm{MHz}, \mathrm{CDCl}_{3}\right): \delta=0.97$ (d, $\left.J=7.0 \mathrm{~Hz}, 6 \mathrm{H}\right), 1.76$ (s, 3H), 2.47 (sept., $J=$ $7.0 \mathrm{~Hz}, 1 \mathrm{H}), 5.83(\mathrm{~m}, 4 \mathrm{H}), 7.26(\mathrm{~d}, J=1.2 \mathrm{~Hz}, 4 \mathrm{H}), 7.39(\mathrm{~m}, 5 \mathrm{H}) .{ }^{31} \mathrm{P}\left\{{ }^{1} \mathrm{H}\right\}-\mathrm{NMR}(81 \mathrm{MHz}$, $\left.\mathrm{CDCl}_{3}\right): \delta=-1(\mathrm{~s})$. ESI-MS $\left(\mathrm{CH}_{3} \mathrm{OH}\right): \mathrm{m} / \mathrm{z}(\%)=513.4(43)[\mathrm{M}-\mathrm{Cl}]^{+}, 477.4(100)[\mathrm{M}-2 \mathrm{Cl}]^{+}$. $\mathrm{C}_{22} \mathrm{H}_{25} \mathrm{Cl}_{2} \mathrm{~N}_{4} \mathrm{PRu} \cdot \mathrm{H}_{2} \mathrm{O}$ (566.43): calc. C 46.65, H 4.80, N 9.89; found C 47.08, H 5.20, N 9.65.

\subsection{3. [(cym)Ru( $\left.\left.\boldsymbol{\kappa}^{2} N, N-2 \boldsymbol{a}\right) \operatorname{Cl}\right] \operatorname{OTf}\left(\mathbf{5} \boldsymbol{a}^{\prime}\right)$}

$\left[\mathrm{Ru}(\mathrm{cym}) \mathrm{Cl}_{2}\right]_{2}(101 \mathrm{mg}, 0.16 \mathrm{mmol})$ and $\operatorname{AgOTf}(85 \mathrm{mg}, 0.33 \mathrm{mmol})$ were dissolved in dry $\mathrm{CH}_{3} \mathrm{CN}(15 \mathrm{~mL})$ and refluxed for 1 hour. Precipitated $\mathrm{AgCl}$ was filtered off and the red filtrate was added to a suspension of $\mathbf{2 a}(80 \mathrm{mg}, 0.33 \mathrm{mmol})$ in dry $\mathrm{CH}_{3} \mathrm{CN}(10 \mathrm{~mL})$. The reaction mixture was refluxed for one hour and stirred for $24 \mathrm{~h}$ at ambient temperature. The resulting yellow solution was concentrated to ca. $3 \mathrm{~mL}$ and $\mathrm{Et}_{2} \mathrm{O}$ was added. The mixture was kept at $-18{ }^{\circ} \mathrm{C}$. The yellow precipitate was filtered off, washed with $\mathrm{Et}_{2} \mathrm{O}$ and dried in vacuo. Yield: $154 \mathrm{mg}(70 \%) .{ }^{1} \mathrm{H}-\mathrm{NMR}\left(200 \mathrm{MHz}\right.$, methanol- $\left.d_{4}\right): \delta=1.31(\mathrm{~d}, J=6.9 \mathrm{~Hz}, 6 \mathrm{H}), 2.04$ (s, 3H), 2.91 (sept., $J=6.9 \mathrm{~Hz}, 1 \mathrm{H}), 5.73(\mathrm{~m}, 4 \mathrm{H}), 7.30$ (d, $J=1.47 \mathrm{~Hz}, 2 \mathrm{H}), 7.46$ (d, $J=1.5$ $\mathrm{Hz}, 2 \mathrm{H}), 7.68(\mathrm{~m}, 5 \mathrm{H}) .{ }^{31} \mathrm{P}\left\{{ }^{1} \mathrm{H}\right\}-\mathrm{NMR}\left(81 \mathrm{MHz}\right.$, methanol- $\left.d_{4}\right): \delta=-22$ (s). ESI-MS $\left(\mathrm{CH}_{3} \mathrm{OH}\right): \mathrm{m} / \mathrm{z}(\%)=493.5(100)[\mathrm{M}+\mathrm{O}]^{+}, 477.5$ (15) $[\mathrm{M}]^{+}, \mathrm{C}_{23} \mathrm{H}_{25} \mathrm{ClF}_{3} \mathrm{~N}_{4} \mathrm{O}_{3} \mathrm{PRuS} \cdot 1 / 2 \mathrm{H}_{2} \mathrm{O}$ (671.03): calc. C 41.16, H 3.91, N 8.49; found C 41.15, H 3.42, N 8.43.

\subsection{4. $\left[(\mathrm{cym}) \mathrm{Ru}\left(\boldsymbol{\kappa}^{2} \mathrm{~N}, \mathrm{~N}-\mathbf{2} \boldsymbol{b}\right) \mathrm{Cl}\right] \mathrm{Cl}(\mathbf{5} \boldsymbol{b})$}

$\left[\mathrm{Ru}(\mathrm{cym}) \mathrm{Cl}_{2}\right]_{2}(100 \mathrm{mg}, 0.16 \mathrm{mmol})$ and $2 \mathbf{b}(118.9 \mathrm{mg}, 0.33 \mathrm{mmol})$ were dissolved in dry $\mathrm{CH}_{3} \mathrm{CN}(15 \mathrm{~mL})$ and stirred for 24 hours. The orange solution was concentrated to $5 \mathrm{ml}$ and $\mathrm{Et}_{2} \mathrm{O}$ was added. The resulting solid was filtered off, washed with $\mathrm{Et}_{2} \mathrm{O}$ and dried in vacuo. Yield: $158 \mathrm{mg}(84 \%)$. ${ }^{1} \mathrm{H}-\mathrm{NMR}\left(200 \mathrm{MHz}, \mathrm{CDCl}_{3}\right): \delta=1.25(\mathrm{~d}, J=7.0 \mathrm{~Hz}, 6 \mathrm{H}), 1.67$ (s, 3H), 2.66 (sept., $J=7.0 \mathrm{~Hz}, 1 \mathrm{H}), 4.20$ (s, 6H), 4.94 (m, 4H), 7.15 (d, $J=1.4 \mathrm{~Hz}, 2 \mathrm{H}), 7.56$ $(\mathrm{m}, 5 \mathrm{H}), 7.83(\mathrm{~d}, J=1.4 \mathrm{~Hz}, 2 \mathrm{H}) .{ }^{31} \mathrm{P}\left\{{ }^{1} \mathrm{H}\right\}-\mathrm{NMR}\left(81 \mathrm{MHz}, \mathrm{CDCl}_{3}\right): \delta=-60$ (s). ESI-MS

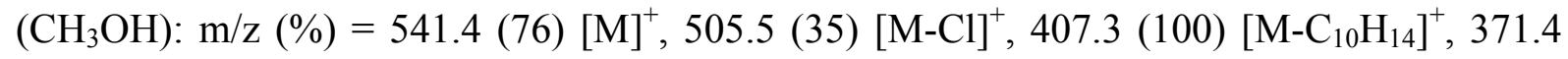
(37) $\left[\mathrm{M}-\mathrm{C}_{10} \mathrm{H}_{14}-\mathrm{Cl}\right]^{+} . \mathrm{C}_{24} \mathrm{H}_{29} \mathrm{Cl}_{2} \mathrm{~N}_{4} \mathrm{PRu} \cdot 2 \mathrm{H}_{2} \mathrm{O}$ (612.50): calc. C 47.1, H 5.4, N 9.1; found $\mathrm{C}$ 47.1, H 5.3, N 9.2.

\subsection{5. $\left[(c y m) R u\left(\kappa^{3} N, N, N-3 a\right)\right] C l_{2}(\boldsymbol{6 a})$}


$\left[\mathrm{Ru}(\mathrm{cym}) \mathrm{Cl}_{2}\right]_{2}(50 \mathrm{mg}, 0.082 \mathrm{mmol})$ and $\mathbf{3 a}(38.2 \mathrm{mg}, 0.16 \mathrm{mmol})$ were dissolved in dry $\mathrm{CH}_{3} \mathrm{CN}(30 \mathrm{~mL})$ and refluxed for 2 hours. The yellow precipitate was collected by filtration, washed with a small amount of $\mathrm{CH}_{3} \mathrm{CN}$ and dried in vacuo. Yield: $21 \mathrm{mg}(24 \%)$. ${ }^{1} \mathrm{H}-\mathrm{NMR}$ (200 MHz, methanol- $\left.d_{4}\right): \delta=1.20(\mathrm{~d}, J=6.7 \mathrm{~Hz}, 6 \mathrm{H}), 2.45$ (s, 3H), 3.24 (sept., $J=6.7 \mathrm{~Hz}$, $1 \mathrm{H}), 6.28(\mathrm{~m}, 4 \mathrm{H}), 7.47(\mathrm{dd}, J=1.6 \mathrm{~Hz}, J=2.94 \mathrm{~Hz}, 3 \mathrm{H}), 8.23(\mathrm{~d}, J=1.6 \mathrm{~Hz}, 3 \mathrm{H}) .{ }^{31} \mathrm{P}\left\{{ }^{1} \mathrm{H}\right\}-$ NMR (81 MHz, methanol- $\left.d_{4}\right): \delta=-103$ (s). ESI-MS $\left(\mathrm{CH}_{3} \mathrm{OH}\right): \mathrm{m} / \mathrm{z}(\%)=467.3(100)[\mathrm{M}]^{+}$, 234 (58) [M-3a $]^{+} . \mathrm{C}_{19} \mathrm{H}_{23} \mathrm{Cl}_{2} \mathrm{~N}_{6} \mathrm{PRu} \cdot 5 / 2 \mathrm{H}_{2} \mathrm{O}$ (583.38): calc. C 39.1, H 4.8, N 14.4; found $\mathrm{C}$ 39.3, H 4.5, N 14.1.

\subsection{6. $\left[(\mathrm{cym}) \mathrm{Ru}\left(\boldsymbol{\kappa}^{3} N, N, N-3 \boldsymbol{b}\right)\right] C l_{2}(\boldsymbol{6} \boldsymbol{b})$}

$\left[\mathrm{Ru}(\mathrm{cym}) \mathrm{Cl}_{2}\right]_{2}(100 \mathrm{mg}, 0.16 \mathrm{mmol})$ and $\mathbf{3 b}(91 \mathrm{mg}, 0.33 \mathrm{mmol})$ were dissolved in dry $\mathrm{CH}_{3} \mathrm{CN}(25 \mathrm{~mL})$ and refluxed for 1.5 hours. The yellow precipitate was collected, washed with a small amount of $\mathrm{CH}_{3} \mathrm{CN}$ and dried in vacuo. Yield: $26 \mathrm{mg}(18 \%) .{ }^{1} \mathrm{H}-\mathrm{NMR}(200$ MHz, methanol- $\left.d_{4}\right): \delta=1.23(\mathrm{~d}, J=6.7 \mathrm{~Hz}, 6 \mathrm{H}), 2.45(\mathrm{~s}, 3 \mathrm{H}), 3.23$ (sept., $J=6.7 \mathrm{~Hz}, 1 \mathrm{H}$ ), $4.03(\mathrm{~s}, 9 \mathrm{H}), 6.29(\mathrm{~m}, 4 \mathrm{H}), 7.55(\mathrm{dd}, J=1.6 \mathrm{~Hz}, J=4.0 \mathrm{~Hz}, 3 \mathrm{H}), 8.21$ (d, $J=1.6 \mathrm{~Hz}, 3 \mathrm{H})$. ${ }^{31} \mathrm{P}\left\{{ }^{1} \mathrm{H}\right\}-\mathrm{NMR}\left(81 \mathrm{MHz}\right.$, methanol- $\left.d_{4}\right): \delta=-116(\mathrm{~s})$. ESI-MS $\left(\mathrm{CH}_{3} \mathrm{OH}\right): \mathrm{m} / \mathrm{z}(\%)=509(100)$ $[\mathrm{M}-\mathrm{Cl}]^{+}, 461$ (29) $\left[\mathrm{M}-\mathrm{C}_{4} \mathrm{~N}_{2} \mathrm{H}_{6}+\mathrm{Cl}\right]^{+} . \mathrm{C}_{22} \mathrm{H}_{29} \mathrm{Cl}_{2} \mathrm{~N}_{6} \mathrm{PRu}$ (580.46): calc. C 45.5, H 5.0, N 14.5; found C 45.2, H 4.9, N 14.1.

\subsection{7. [(cym)Ru( $\left.\left.\kappa^{2} N, N-e n\right) C l\right] C l(7)$}

$\left[\mathrm{Ru}(\mathrm{cym}) \mathrm{Cl}_{2}\right]_{2}(100 \mathrm{mg}, 0.16 \mathrm{mmol})$ was solved in dry $\mathrm{CH}_{3} \mathrm{CN}(25 \mathrm{~mL})$. A yellow solid precipitated upon addition of an excess of ethylendiammine (en). The reaction mixture was stirred for 20 minutes to complete the reaction. The solid was filtered off, washed with dry $\mathrm{CH}_{3} \mathrm{CN}$ and dried in vacuo. Yield: $99 \mathrm{mg}(84 \%)$. ${ }^{1} \mathrm{H}-\mathrm{NMR}\left(200 \mathrm{MHz}\right.$, methanol- $\left.d_{4}\right): \delta=1.27$ (d, $J=7.0 \mathrm{~Hz}, 6 \mathrm{H}), 2.43$ (s, 3H), 2.70 (m, br, 4H), 2.81 (sept., $J=7.0 \mathrm{~Hz}, 1 \mathrm{H}), 5.81$ (m, 4H). ESI-MS $\left(\mathrm{CH}_{3} \mathrm{OH}\right): \mathrm{m} / \mathrm{z}(\%)=295(100)[\mathrm{M}-\mathrm{Cl}]^{+}, 235(34)[\mathrm{M}-\mathrm{Cl}-\mathrm{en}]^{+}$.

\subsection{Distribution coefficients $(\log D)$}

The $n$-octanol-water distribution coefficients of the compounds were determined using a shake-flask method. PBS buffered bi-distilled water $\left(100 \mathrm{~mL}\right.$, phosphate buffer, $c\left(\mathrm{PO}_{4}{ }^{3-}\right)=10$ $\mathrm{mM}, c(\mathrm{NaCl})=0.15 \mathrm{M}, \mathrm{pH}$ adjusted to 7.4 with $\mathrm{HCl})$ and $n$-octanol $(100 \mathrm{~mL})$ were shaken together using a laboratory shaker (Perkin Elmer), for $72 \mathrm{~h}$ to allow saturation of both phases. $1 \mathrm{mg}$ of each compound was mixed in $1 \mathrm{~mL}$ of aqueous and organic phase, respectively for 10 min using a laboratory vortexer. The resultant emulsion was centrifuged (3000 $\mathrm{g}, 5 \mathrm{~min})$ to 
separate the phases. The concentrations of the compounds in the organic and aqueous phases were then determined using UV absorbance spectroscopy $(230 \mathrm{~nm}) . \log D_{\mathrm{pH}}$ was defined as the logarithm of the ratio of the concentrations of the complex in the organic and aqueous phases $\log D=\log \left(\left[\operatorname{compound}_{(\mathrm{org})}\right] /\left[\operatorname{compound}_{(\mathrm{aq})}\right]\right)$, the value reported is the mean of three separate determinations.

\subsection{DNA Binding Studies}

The UV/Vis kinetic studies and thermal denaturation temperature $T_{\mathrm{m}}$ determinations for 1:5 complex/ DNA mixtures $[$ DNA concentration $=\mathrm{M}$ (base pairs) $]$ were performed in a $10 \mathrm{mM}$ phosphate buffer at $\mathrm{pH}=7.4$. Melting curves were recorded at $2{ }^{\circ} \mathrm{C}$ steps for the wavelength $260 \mathrm{~nm}$ with an Analytik Jena SPECORD 100 spectrometer and a thermostat. $\Delta T_{\mathrm{m}}$ values were calculated by determining the midpoints of melting curves. The experimental $\Delta T_{\mathrm{m}}$ values are estimated to be accurate within $\pm 1{ }^{\circ} \mathrm{C}$. Concentrations of calf thymus (ct) DNA were determined spectrophotometrically using the molar extinction coefficient $\varepsilon_{260}=13200$ $\mathrm{M}^{-1} \mathrm{~cm}^{-1}$.38]

\subsection{Cell culture}

Hct116 human colon carcinoma and H4IIE rat hepatoma cells were grown in Dulbecco's modified Eagle's medium (DMEM, GIBCO; Germany), A2780 human ovarian carcinoma cells were grown in RPMI cell culture medium; all media contained $10 \%$ fetal calf serum (PAA Laboratories; Austria), penicillin $(100 \mathrm{U} / \mathrm{mL})$ and streptomycin $(100 \mu \mathrm{g} / \mathrm{mL})$ at $5 \%$ $\mathrm{CO}_{2}$ and $37^{\circ} \mathrm{C}$.

\subsection{Determination of cytotoxicity}

The effect of the compounds on cell viability was determined using the MTT assay. ${ }^{[39]}$ Cells were plated on 96-multiwell plates (H4IIE, Hct116 cells: 15.000 / well, A2780 cells: 35.000 / well), allowed to attach for $24 \mathrm{~h}$ and then treated with different concentrations of the substances for indicated time points. In all experiments compounds were dissolved in dmso. The dmso concentration was equal at all compound concentrations analyzed. The highest dmso concentration used was $1 \%$; no toxic effect was detected at this concentration. After treatment medium was changed and cells were incubated for $30 \mathrm{~min}$ under cell culture conditions with $1 \mathrm{mg} / \mathrm{mL}$ MTT. Then the cells were lysed with $100 \%$ dmso. The concentration of reduced MTT as a marker for cell viability was measured photometrically (560 nm) using a Wallace Victor2 1420 multilabel counter (Perkin-Elmer). 


\subsection{Statistical analysis}

All data were analyzed using one-way analysis of variance, followed by Bonferroni or Dunnet post hoc analysis to determine statistical significance. $P$ values $<0.05$ were considered statistically significant. The analysis was performed with GraphpadPrism 5.0c.

\subsection{Crystallography}

Crystals of compounds $\mathbf{5 a}$ and $\mathbf{5 a}$ '. $\mathrm{CH}_{2} \mathrm{Cl}_{2}$ suitable for X-ray study were selected by means of a polarisation microscope and investigated with a STOE Imaging Plate Diffraction System, using graphite monochromatized MoK $\alpha$ radiation $(\lambda=0.71073 \AA)$. Unit cell parameters were determined by least-squares refinements on the positions of 8000 reflections. Space group type no. 14 was uniquely determined for both compounds. Corrections for Lorentz and polarization effects were applied. The structures were solved by direct methods (SHELXS$86)^{[40]}$ and subsequent $\Delta F$-syntheses. Approximate positions of all the hydrogen atoms were found in different stages of converging refinements by full-matrix least-squares calculations on $F^{2}{ }^{[40]}$ Anisotropic displacement parameters were refined for all atoms heavier than hydrogen. With idealised bonds lengths and angles assumed for all the $\mathrm{CH}, \mathrm{CH}_{2}$ and $\mathrm{CH}_{3}$ groups, the riding model was applied for the corresponding $\mathrm{H}$ atoms and their isotropic displacement parameters were constrained to $120 \%, 120 \%$ and $150 \%$ of the equivalent isotropic displacement parameters of the parent carbon atoms, respectively. In addition, the $\mathrm{H}$ atoms of the $\mathrm{CH}_{3}$ groups were allowed to rotate around the neighboring $\mathrm{C}-\mathrm{C}$ bonds. Crystallographic data of $\mathbf{5 b} \cdot 2 \mathrm{CH}_{3} \mathrm{CN} \cdot 1 / 2 \mathrm{H}_{2} \mathrm{O}$ were collected at $183(2) \mathrm{K}$ on an Oxford Diffraction Xcalibur system with a Ruby detector using Mo K $\alpha$ radiation $(\lambda=0.7107 \AA)$ that was graphite-monochromated. Suitable crystals were covered with oil (Infineum V8512, formerly known as Paratone N), mounted on top of a glass fibre and immediately transferred to the diffractometer. The program suite CrysAlisPro was used for data collection, multi-scan absorption correction and data reduction. ${ }^{[41]}$ The structure was solved with direct methods using SIR97 ${ }^{[42]}$ and was refined by full-matrix least-squares methods on $\mathrm{F}^{2}$ with SHELXL97. ${ }^{[40]}$ The structure was checked for higher symmetry with help of the program Platon. ${ }^{[43]}$ CCDC entries 867104 (5a), $867105\left(\mathbf{5 a} \cdot{ }^{\circ} \mathrm{CH}_{2} \mathrm{Cl}_{2}\right)$ and $861637\left(\mathbf{5 b} \cdot 2 \mathrm{CH}_{3} \mathrm{CN} \cdot 1 / 2 \mathrm{H}_{2} \mathrm{O}\right)$ contain the supplementary crystallographic data (excluding structure factors) for this paper. These data can be obtained free of charge from The Cambridge Crystallographic Data Centre via www.ccdc.cam.ac.uk/data_request/cif. 


\section{Results and Discussion}

\subsection{Syntheses and characterisation}

We prepared the $(\mathrm{cym}) \mathrm{Ru}$ complexes $(\mathrm{cym}=p$-cymene $)$ by reaction of $\left[\left\{(\mathrm{cym}) \mathrm{RuCl}_{2}\right\}_{2}\right]$ and the corresponding ligands $\mathbf{1 a , b}-\mathbf{3 a}, \mathbf{b}$ in acetonitrile (Scheme 1). The corresponding complexes precipitated from solution or were obtained in analytically pure form after addition of $\mathrm{Et}_{2} \mathrm{O}$.

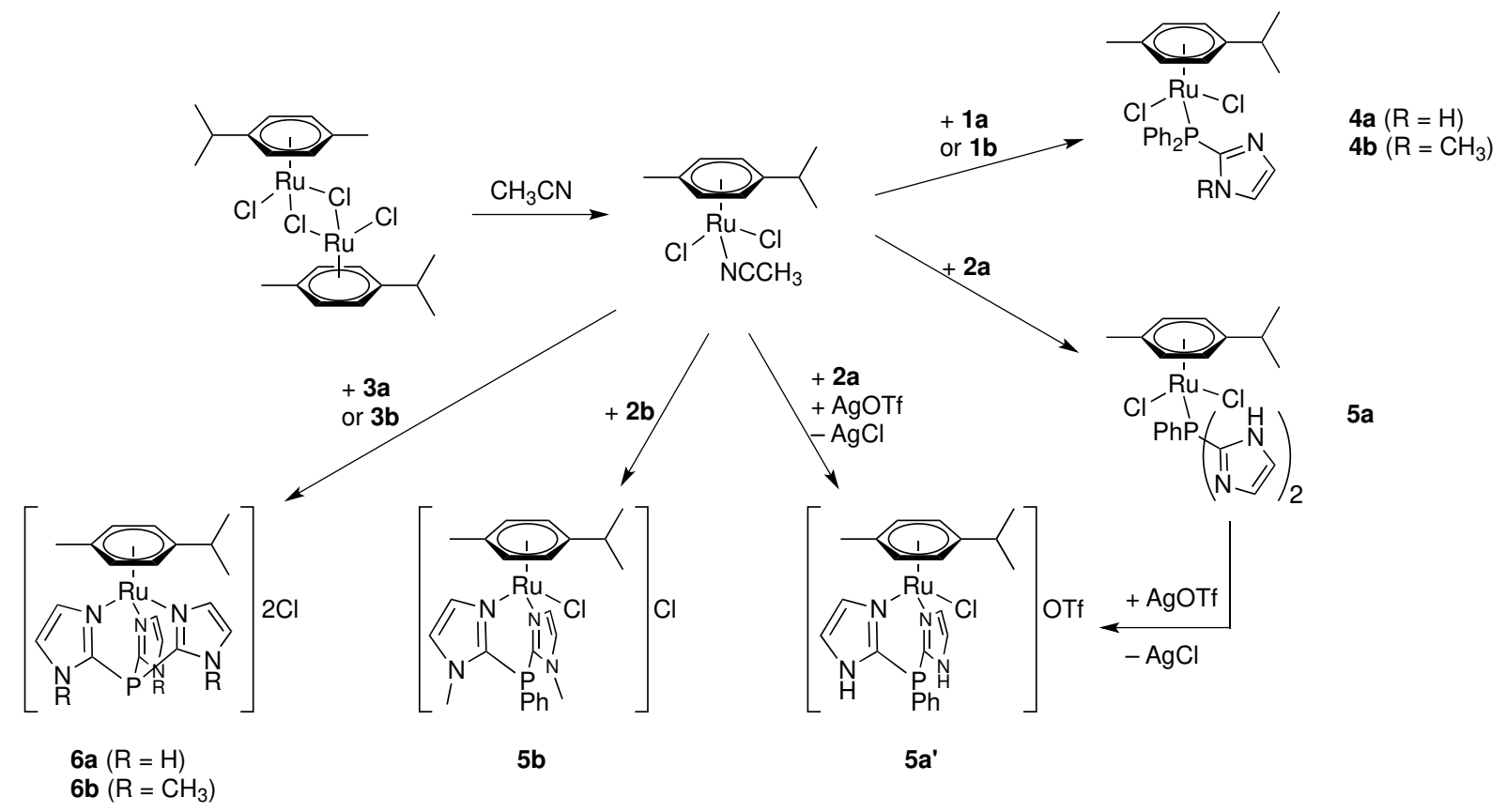

Scheme 1. Reaction of $\left[\left\{(\mathrm{cym}) \mathrm{RuCl}_{2}\right\}_{2}\right]$ in acetonitrile with ligands $\mathbf{1}-\mathbf{3}$ yields compounds $\mathbf{4}$ 6.

All compounds exhibit sharp singlet resonances in their ${ }^{31} \mathrm{P}\left\{{ }^{1} \mathrm{H}\right\}$ NMR spectra (Table 1). The analytical data of complex $\mathbf{4 a}$ are nearly identical to the one of $\mathbf{1 b}$ which has been previously described by Caballero et al. Complexes 6a and $\mathbf{6 b}$ show one set of signals for the ligands in the ${ }^{1} \mathrm{H}$ NMR (methanol- $d_{4}$ ), indicating local $C_{3 \mathrm{v}}$ symmetry. Additionally, their ${ }^{31} \mathrm{P}\left\{{ }^{1} \mathrm{H}\right\} \mathrm{NMR}$ spectra show the typical coordination shift to about $-110 \mathrm{ppm}$ which is indicative for the $\kappa^{3} N, N, N$ coordination mode in complexes of tris(imidazolyl)phosphine ligands. ${ }^{[44-46]}$ 
Table 1. ${ }^{31} \mathrm{P}\left\{{ }^{1} \mathrm{H}\right\}$ resonances $\left(\delta_{\mathrm{C}}\right)$ of the $($ cym $) \mathrm{Ru}$ complexes $\mathbf{4 a , b}-\mathbf{6 a}, \mathbf{b}$ and the corresponding coordination shifts $\left(\Delta \delta=\delta_{\mathrm{C}}-\delta_{\mathrm{L}},{ }^{a}\right.$ in methanol- $d_{4},{ }^{b}$ in $\left.\mathrm{CDCl}_{3}\right)$.

\begin{tabular}{ccc}
\hline Compound & $\delta\left({ }^{31} \mathrm{P}\right) / \mathrm{ppm}$ & $\Delta \delta\left({ }^{31} \mathrm{P}\right) / \mathrm{ppm}$ \\
\hline $\mathbf{4 a}$ & $22^{\boldsymbol{a}}$ & +45 \\
$\mathbf{4 b}$ & $8^{\boldsymbol{b}}$ & +35 \\
$\mathbf{5 a}$ & $1^{\boldsymbol{b}}$ & +46 \\
$\mathbf{5 a}$ & $-22^{a}$ & +23 \\
$\mathbf{5 b}$ & $-60^{\boldsymbol{b}}$ & -15 \\
$\mathbf{6 a}$ & $-103^{a}$ & -43 \\
$\mathbf{6 b}$ & $-116^{\boldsymbol{a}}$ & -44 \\
\hline
\end{tabular}

The ligands $\mathbf{1 a} / \mathbf{b}$ in complexes $\mathbf{4 a}$ and $\mathbf{4 b}$ show the $\kappa P$ coordination mode and the ligands $\mathbf{3 a} / \mathbf{b}$ in complexes $\mathbf{6 a}$ and $\mathbf{6 b}$ show the $\kappa^{3} N, N, N$ mode. The coordination modes found in the isolated complexes of ligands $\mathbf{2 a}$ and $\mathbf{2 b}$ are more complex. Initially, the reaction of $\left[\left\{(\mathrm{cym}) \mathrm{RuCl}_{2}\right\}_{2}\right]$ with the PN phosphine ligands proceeds via a $\mathrm{P}$ coordinated species. The course of the reactions was monitored by ${ }^{31} \mathrm{P}$ NMR and even during formation of $\mathbf{6 a}$ and $\mathbf{6 b}$ signals for a transient species, tentatively assigned to $\kappa P$ species (see Fig. ESI1), was observed. All attempts to 'trap' $\kappa P$ bound ligands $\mathbf{3 a} / \mathbf{b}$, e.g. by reaction of these ligands with $[(\mathrm{cym}) \mathrm{Ru}(\mathrm{en}) \mathrm{Cl}](7)$, finally resulted in formation of compounds $\mathbf{6 a}$ and $\mathbf{6} \mathbf{b}$, respectively.

When ligands $\mathbf{2 a}$ and $\mathbf{2 b}$ were used, $\kappa P$ coordination can compete with the chelating $\kappa^{2} N, N$ binding mode. Those coordination modes were found in compounds $\mathbf{5} \mathbf{a}$ ' and $\mathbf{5 b}$ (both $\kappa^{2} N, N$ ) and 5a $(\kappa P)$ which were unambiguously assigned by their single crystal structures (see below). As mentioned previously, $\kappa P$ coordination leads to a classical coordination shift of the ${ }^{31} \mathrm{P}$ resonance towards lower field whereas chelating $\kappa^{2} N, N\left(\right.$ or $\kappa^{3} N, N, N$ in $\left.\mathbf{6 a}, \mathbf{b}\right)$ results in a shift towards higher field (Table 1$)$. The reaction of $\mathbf{2 b}$ with $\left[\left\{(\mathrm{cym}) \mathrm{RuCl}_{2}\right\}_{2}\right]$ yields $\mathbf{5} \mathbf{b}$, where only $\kappa^{2} N, N$ coordination of $\mathbf{2 b}$ is observed. The related ligand $\mathbf{2 a}$ can adopt both coordination $\kappa P$ and $\kappa^{2} N, N$ modes depending on the chloride concentration in solution. The reaction of stoichiometric amounts of $\left[\left\{(\mathrm{cym}) \mathrm{RuCl}_{2}\right\}_{2}\right]$ and $\mathbf{2 a}$ gives a mixture of $\left[(\mathrm{cym}) \mathrm{Ru}\left(\kappa^{2} P-\mathbf{2 a}\right) \mathrm{Cl}_{2}\right](\mathbf{5 a})$ and $\left[(\mathrm{cym}) \mathrm{Ru}\left(\kappa^{2} N, N-\mathbf{2 a}\right) \mathrm{Cl}\right]^{+}$and unreacted ligand (Fig. 1). Addition of one equivalent of $\mathrm{Ag}\left(\mathrm{O}_{3} \mathrm{SCF}_{3}\right)$ to that reaction mixture quantitatively yields $\mathbf{5} \mathbf{a}^{\text {'. }}$ This reaction is not reversible as $\mathbf{5} \mathbf{a}^{\mathbf{\prime}}$ is persistent even in the presence of high chloride 
concentration (up to $>100$ fold) as was shown by ${ }^{31} \mathrm{P}$ NMR spectroscopy. Therefore small electronic changes in the ligand system, like introduction of electron donating methyl groups, can favour one binding mode over the other. This might be of importance as this might alter their cytotoxicity profiles, e.g. in the presence of other coordinating ligands as chloride.

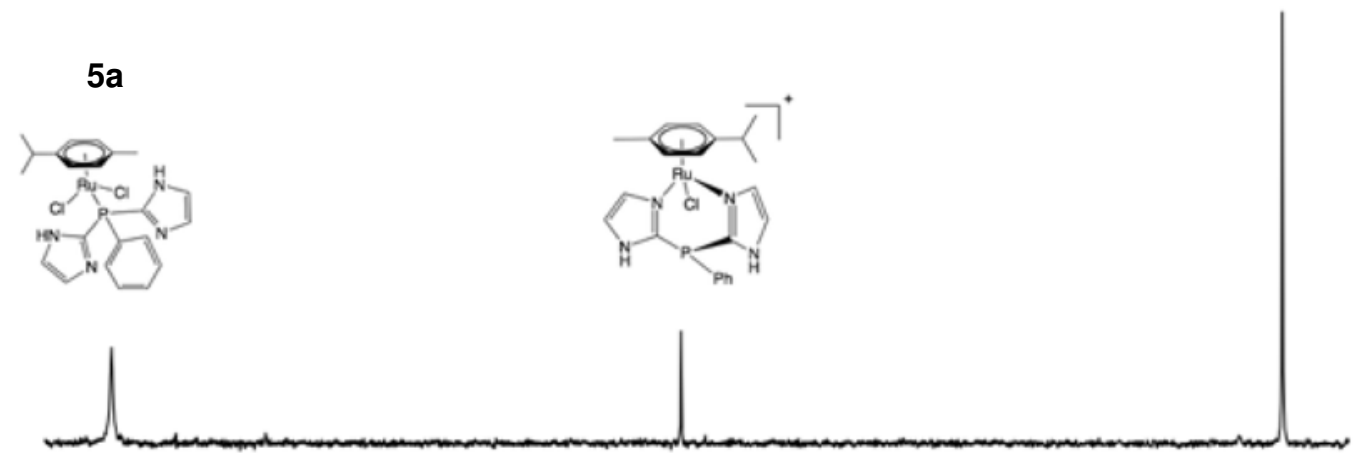

Fig. 1. ${ }^{31} \mathrm{P}\left\{{ }^{1} \mathrm{H}\right\}$-NMR spectrum of the reaction mixture of $\left[\left\{(\mathrm{cym}) \mathrm{RuCl}_{2}\right\}_{2}\right]$ and $\mathbf{2 a}$ in dmso$d_{6}$. The ligand $\mathbf{2 a}$ and complexes $\left[(\mathrm{cym}) \mathrm{Ru}\left(\kappa^{2} P-\mathbf{2 a}\right) \mathrm{Cl}_{2}\right](\mathbf{5 a})$ and $\left[(\operatorname{cym}) \mathrm{Ru}\left(\kappa^{2} N, N-\mathbf{2 a}\right) C l\right]^{+}$ with $\kappa P$ and $\kappa^{2} N, N$ coordination mode show resonances at $-50,3$ and $23 \mathrm{ppm}$.

\subsection{Solid-state structures}

The solid-state structures of compounds $\mathbf{5 a}$, $\mathbf{5 a}$ and $\mathbf{5 b}$ were determined by single crystal analysis and crystallographic data is summarized in Table 2. Compounds 5a' and 5a crystallised in the monoclinic space group $P 2_{1} / \mathbf{c}$. Compound $\mathbf{5 b}$ crystallised as solvate 5b $3 \mathrm{CH}_{3} \mathrm{CN}^{\cdot} 1 / 2 \mathrm{H}_{2} \mathrm{O}$ in the monoclinic space group $P 2_{1} / \mathrm{n}$. The ruthenium atom in all structures is in octahedral coordination sphere with the $\eta^{6}$-cymene ligand occupying one face of the octahedron. In 5a the other three positions are occupied by two chlorido ligands and $\kappa P$ bound 2a (Fig. 2). In 5a' and $\mathbf{5} \mathbf{b}$ the $\kappa^{2} N, N$-coordination mode of the PNN ligands $\mathbf{2 a}$ and $\mathbf{2 b}$ is found (Fig. 3 and Fig. 4). The ruthenium atom is coordinated by $\mathbf{2 a} / \mathbf{b}$ in the chelating $\kappa^{2} N, N$ mode and a chlorido ligand. The other chloride or $\mathrm{CF}_{3} \mathrm{SO}_{3}{ }^{-}$acts as counter-ion to the complex cations, respectively. The metric parameters found in $\mathbf{5 a}$ and $\mathbf{5 a} \mathbf{9} / \mathbf{5 b}$ are within the range 
found for other compounds $\left[(\mathrm{cym}) \mathrm{Ru}\left(\mathrm{PR}_{3}\right) \mathrm{Cl}_{2}\right]^{[31,35,47-49]}$ and complexes $[(\mathrm{cym}) \mathrm{Ru}(\mathrm{N}-\mathrm{N}) \mathrm{Cl}]^{+}$ with diammino ligands ${ }^{[31,50,51]}$.

In the solid-state structures of $\mathbf{5 a}$ and $\mathbf{5 b}$ the phenyl substituents of the corresponding ligand $\mathbf{2 a} / \mathbf{b}$ and the $p$-cymene ligand at the ruthenium atom adopt cis (5b) and trans positions (5a') (Scheme 2). The compounds 5a and 5a', bearing ligand 2a with NH functionalities, show hydrogen bonding in their solid-state structures.

In the solid state of 5a' intermolecular hydrogen bonds are formed between $\mathrm{N} 2 \mathrm{H} 1{ }^{\cdots}{ }^{\cdots} \mathrm{O} 1_{\text {(triflate) }}$ and $\mathrm{N} 4 \mathrm{H} 2 \cdots \mathrm{Cl} 1$ thus forming one-dimensional arrays. Also in the solid state of 5a the intermolecular hydrogen bonds $\mathrm{N} 3 \mathrm{H} 2 \cdots \mathrm{Cl} 2$ result in formation of one-dimensional arrays. Additionally a weak bifurcated intramolecular hydrogen bond between N1H1 and Cl1 and $\mathrm{Cl} 2$ is found.

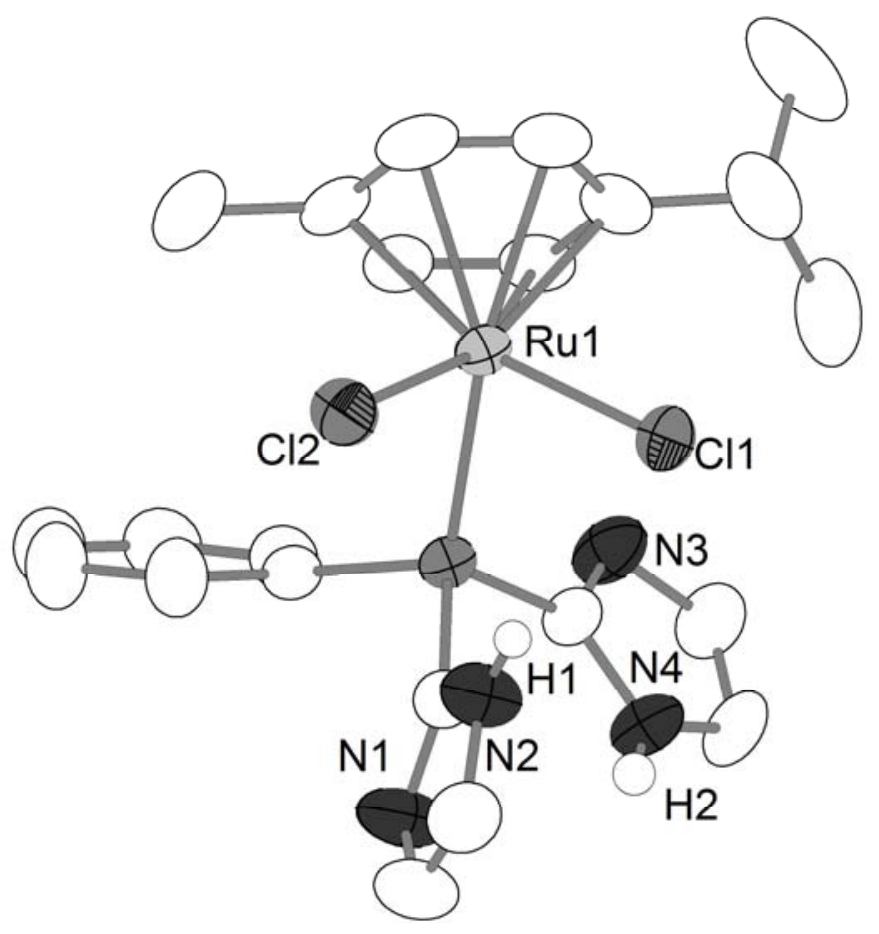

Fig. 2. Molecular structure of 5a. Non-acidic hydrogen atoms are omitted for clarity. The displacement ellipsoids are shown on a $50 \%$ level. Selected bond lengths $[\AA]$ and angles $\left[^{\circ}\right]$ : Ru1-P1 2.3477(7), Ru1-Cl1 2.4173(7), Ru1-Cl2 2.4165(8), P1-Ru1-Cl1 87.41(3), P1-Ru1$\mathrm{Cl} 2$ 86.60(3), Cl1-Ru1-Cl2 87.39(3). 


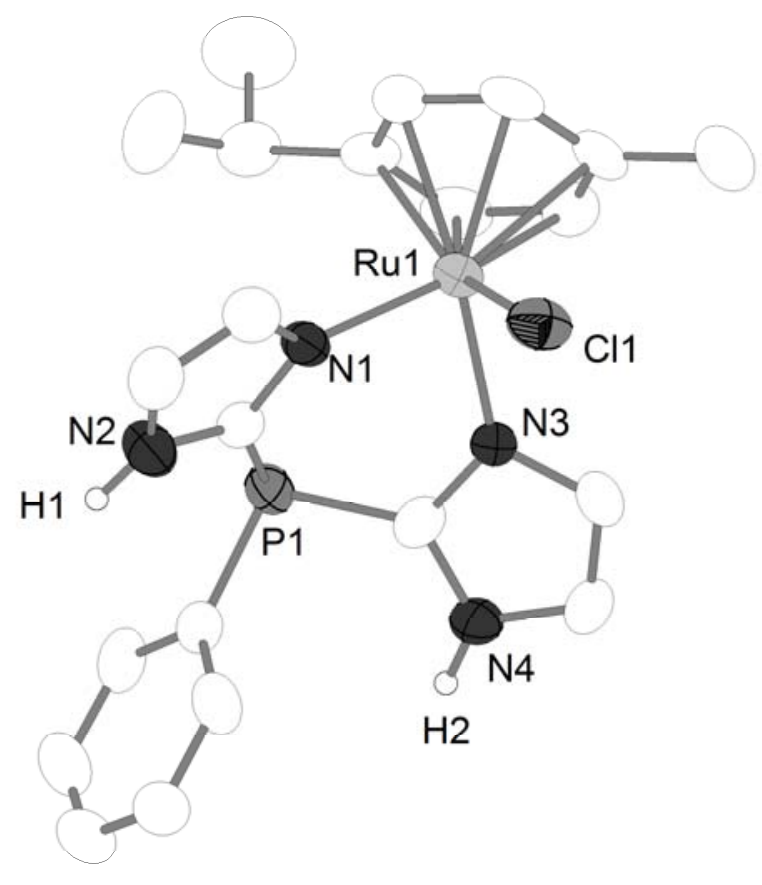

Fig. 3. Molecular structure of $\mathbf{5} \mathbf{a}^{\prime} \cdot \mathrm{CH}_{2} \mathrm{Cl}_{2}$. Uncoordinated counter ion, non-acidic hydrogen atoms and solvent molecule are omitted for clarity. The displacement ellipsoids are shown on a 50\% level. Selected bond lengths $[\AA]$ and angles $\left[{ }^{\circ}\right]$ : Ru1-N1 2.096(4), Ru1-N3 2.087(3), Ru1-Cl1 2.4006(15), N1-Ru1-N3 84.28(14), N1-Ru1-Cl1 85.21(12), N3-Ru1-Cl1 85.84(11).

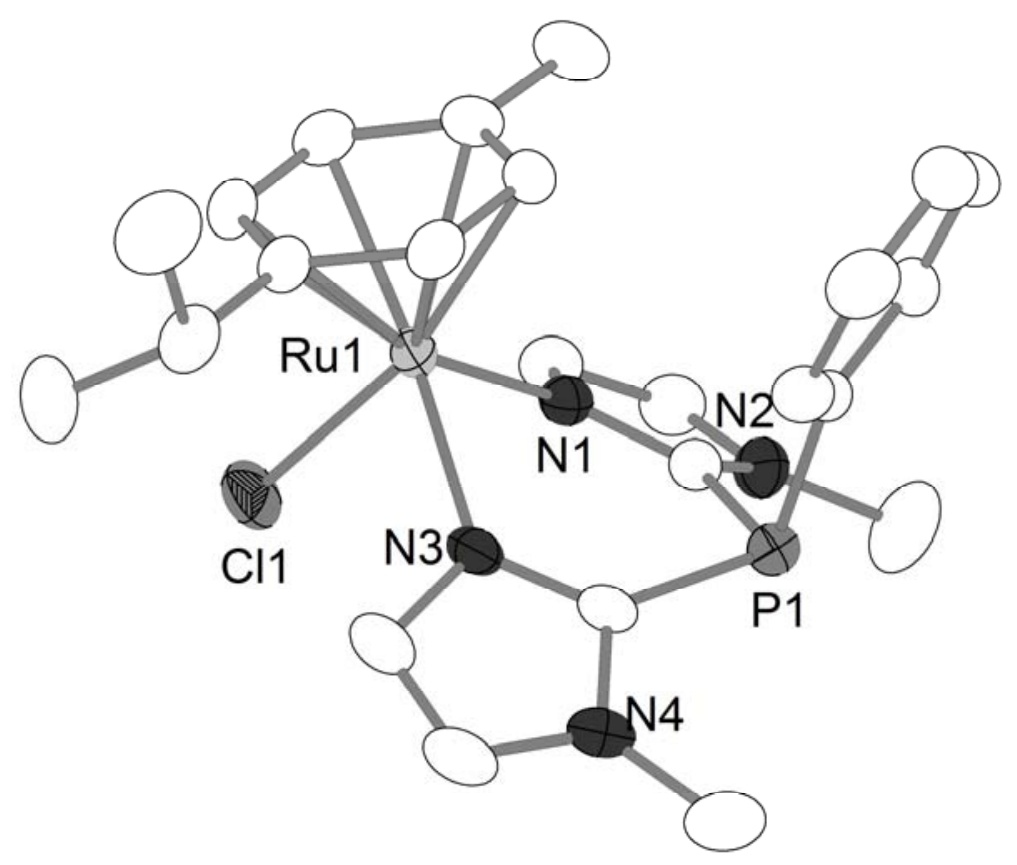

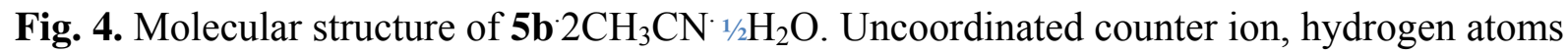
and solvent molecules are omitted for clarity. The displacement ellipsoids are shown on a 
50\% level. Selected bond lengths $[\AA]$ and angles $\left[^{\circ}\right]$ : Ru1-N1 2.090(2), Ru1-N3 2.097(2), Ru1-Cl1 2.3897(7), N1-Ru1-N3 2.3897(7), N1-Ru1-Cl1 85.21(6) N3-Ru1-Cl1 84.61(6).
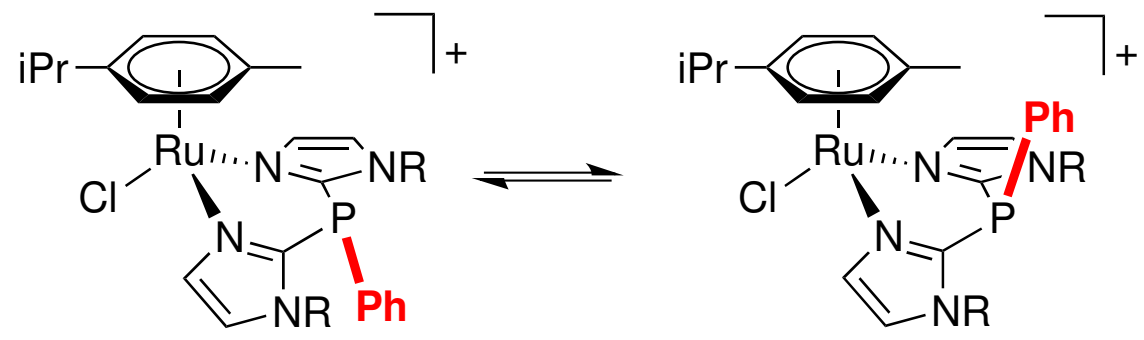

Scheme 2. The trans and cis isomers found in the solid-state structures of $\mathbf{5 a}$ ' $(\mathrm{R}=\mathrm{H})$ and $\mathbf{5 b}$ $\left(\mathrm{R}=\mathrm{CH}_{3}\right)$.

Table 2. Crystallographic data for compounds $\mathbf{5 a}$, 5a' and $\mathbf{5} \mathbf{b}^{\cdot} 2 \mathrm{CH}_{3} \mathrm{CN}^{\cdot 1 / 2} \mathrm{H}_{2} \mathrm{O}$.

\begin{tabular}{|c|c|c|c|}
\hline Compound & $5 \mathbf{a}$ & 5a'. $\mathrm{CH}_{2} \mathrm{Cl}_{2}$ & $\mathbf{5 b} \cdot 2 \mathrm{CH}_{3} \mathrm{CN}^{\cdot 1 / 2} \mathrm{H}_{2} \mathrm{O}$ \\
\hline Empirical formula & $\mathrm{C}_{22} \mathrm{H}_{25} \mathrm{Cl}_{2} \mathrm{~N}_{4} \mathrm{PRu}$ & $\mathrm{C}_{24} \mathrm{H}_{27} \mathrm{Cl}_{3} \mathrm{~F}_{3} \mathrm{~N}_{4} \mathrm{O}_{3} \mathrm{PRuS}$ & $\mathrm{C}_{28} \mathrm{H}_{36} \mathrm{Cl}_{2} \mathrm{~N}_{6} \mathrm{O}_{0.5} \mathrm{PRu}$ \\
\hline Formula weight & 548.40 & 746.96 & 667.57 \\
\hline Temperature / K & 291(2) & $291(2)$ & $183(2)$ \\
\hline Wavelength / $\AA$ & 0.71073 & 0.71073 & 0.71073 \\
\hline Crystal system & Monoclinic & Monoclinic & Monoclinic \\
\hline Space group & $P 2_{1} / \mathrm{c}$ & $P 2_{1} / \mathrm{c}$ & $P 2_{1} / \mathrm{n}$ \\
\hline Unit cell dimensions & & & \\
\hline$a / \AA$ & $17.2041(9)$ & $14.985(2)$ & $10.98070(16)$ \\
\hline$b / \AA$ & $9.7578(8)$ & $7.7408(8)$ & $12.8114(2)$ \\
\hline$c / \AA$ & $14.1705(7)$ & $26.642(4)$ & 23.9097(4) \\
\hline$\alpha /{ }^{\circ}$ & 90 & 90 & 90 \\
\hline$\beta / \circ$ & $103.729(6)$ & $98.273(18)$ & $93.5635(14)$ \\
\hline$\gamma / \circ$ & 90 & 90 & 90 \\
\hline Volume / $\AA^{3}$ & $2310.9(3)$ & $3058.2(7)$ & $3357.07(9)$ \\
\hline$Z$ & 4 & 4 & 4 \\
\hline $\begin{array}{l}\text { Density (calculated) / } \\
\mathrm{Mg} / \mathrm{m}^{3}\end{array}$ & 1.576 & 1.622 & 1.321 \\
\hline $\begin{array}{l}\text { Absorption coefficient / } \\
\mathrm{mm}^{-1}\end{array}$ & 0.996 & 0.947 & 0.701 \\
\hline $\mathrm{F}(000)$ & 1112 & 1504 & 1372 \\
\hline Crystal size $/ \mathrm{mm}^{3}$ & $0.3 \times 0.3 \times 0.3$ & $0.2 \times 0.2 \times 0.2$ & $0.24 \times 0.18 \times 0.11$ \\
\hline $\begin{array}{l}\text { Theta range for data } \\
\text { collection }\end{array}$ & 2.42 to $24.99^{\circ}$ & 1.91 to $25.92^{\circ}$ & 2.63 to $33.14^{\circ}$ \\
\hline Index ranges & $\begin{array}{l}-20<=\mathrm{h}<=20 \\
-11<=\mathrm{k}<=11 \\
-16<=\mathrm{l}<=16\end{array}$ & $\begin{array}{l}-18<=\mathrm{h}<=18 \\
-9<=\mathrm{k}<=9 \\
-32<=\mathrm{l}<=32\end{array}$ & $\begin{array}{l}-16<=\mathrm{h}<=14 \\
-19<=\mathrm{k}<=13 \\
-36<=1<=36\end{array}$ \\
\hline Reflections collected & 29702 & 35580 & 31289 \\
\hline Independent reflections & $\begin{array}{l}4013[\mathrm{R}(\text { int })= \\
0.0438]\end{array}$ & $5920[\mathrm{R}(\mathrm{int})=0.0977]$ & $\begin{array}{l}12777[\mathrm{R}(\mathrm{int})= \\
0.0355]\end{array}$ \\
\hline Completeness to theta & $98.3 \%$ to $24.99^{\circ}$ & $99.4 \%$ to $25.92^{\circ}$ & $99.9 \%$ to $33.14^{\circ}$ \\
\hline Absorption correction & None & None & $\begin{array}{l}\text { Semi-empirical } \\
\text { from equivalents }\end{array}$ \\
\hline Refinement method & $\begin{array}{l}\text { Full-matrix least- } \\
\text { squares on } \mathrm{F}^{2}\end{array}$ & $\begin{array}{l}\text { Full-matrix least- } \\
\text { squares on } \mathrm{F}^{2}\end{array}$ & $\begin{array}{l}\text { Full-matrix least- } \\
\text { squares on } \mathrm{F}^{2}\end{array}$ \\
\hline Data / restraints / & $4013 / 0 / 279$ & $5920 / 0 / 364$ & $12777 / 7 / 380$ \\
\hline
\end{tabular}




\begin{tabular}{llll}
\hline parameters & & & \\
Goodness-of-fit on $\mathrm{F}^{2}$ & 1.045 & 0.932 & 0.967 \\
Final R indices & $\mathrm{R}_{1}=0.0283, w \mathrm{R}_{2}$ & $\mathrm{R}_{1}=0.0373, w \mathrm{R}_{2}=$ & $\mathrm{R}_{1}=0.0456, w \mathrm{R}_{2}=$ \\
{$[\mathrm{I}>$ 2sigma(I)] } & $=0.0665$ & 0.0603 & 0.1232 \\
$\mathrm{R}$ indices (all data) & $\mathrm{R}_{1}=0.0365, w \mathrm{R}_{2}$ & $\mathrm{R}_{1}=0.1079, w \mathrm{R}_{2}=$ & $\mathrm{R}_{1}=0.0790, w \mathrm{R}_{2}=$ \\
& $=0.0681$ & 0.0653 & 0.1324 \\
& 0.626 and -0.323 & 0.569 and -0.650 & 1.027 and -0.703 \\
Largest diff. peak and & & \\
hole / e. $\AA^{-3}$ & & & \\
\hline
\end{tabular}

\subsection{Biological studies}

Biological studies were performed on compounds $\mathbf{4 a , b}, \mathbf{5 a}, \mathbf{b}$ and $\mathbf{5 a}$ ' as well as $\mathbf{6 a}$ and $\mathbf{6 b}$. The n-octanol-water distribution coefficients of compounds $\mathbf{4 a , b}, \mathbf{5 a}, \mathbf{b}$ and $\mathbf{5 a}$ ' were determined as $\log D_{7.4}$ values using phosphate buffered saline (PBS). The $\log D_{7.4}$ value decreases within the series $\mathbf{4 a}>\mathbf{4} \mathbf{b}>\mathbf{5 a} \mathbf{a}>\mathbf{5 a}>\mathbf{5 b}$ (Table 3). The introduction of additional imidazolyl groups in the $\kappa P$ complexes increases the water-solubility of the compounds as does the introduction of charge in complexes $\mathbf{5 a} / \mathbf{b}$. Surprisingly, the complexes having $N$ methyl groups in the PN ligands are more water soluble than their NH-congeners.

A decrease in thermal denaturation temperature of $7^{\circ} \mathrm{C}$ in the presence of $\mathbf{4 a}, \mathbf{4 b}$ and $\mathbf{5 a}$, respectively and of $4{ }^{\circ} \mathrm{C}$ in the presence $\mathbf{5 b}$ was recorded for calf-thymus DNA (ctDNA) at a molar ratio of $r=0.2$ where [DNA] is given in M(base pairs) (Table 3 and Supporting Information). Interestingly, the melting curve in the presence of 5a shows two stages corresponding to decreases in thermal denaturation temperature of 8 and $28{ }^{\circ} \mathrm{C}$ respectively. This might reflect a rearrangement of the coordination mode of the ligand in the complex as discussed before.

Table 3. Experimental $n$-octanol/water (PBS buffer $\mathrm{pH}$ 7.4) distribution coefficients $\left(\log D_{7.4}\right)$ and DNA melting temperatures $\left(\Delta T_{\mathrm{m}}\right)$ at a ratio of metal complex / DNA (in base pairs) of 1 / 5. The $\Delta T_{\mathrm{m}}$ values are estimated to be accurate within $\pm 1{ }^{\circ} \mathrm{C}$.

\begin{tabular}{cccc}
\hline Compound & $\log D_{7.4}$ & $T_{\mathrm{m}} /{ }^{\circ} \mathrm{C}$ & $\Delta T_{\mathrm{m}} /{ }^{\circ} \mathrm{C}$ \\
\hline $\mathbf{4 a}$ & $1.25 \pm 0.03$ & 66 & 7 \\
$\mathbf{4 b}$ & $1.14 \pm 0.05$ & 66 & 7 \\
$\mathbf{5 a}$ & $0.14 \pm 0.03$ & 45,65 & 28,8 \\
$\mathbf{5 a}$ & $-0.33 \pm 0.02$ & 66 & 7 \\
$\mathbf{5 b}$ & $-0.68 \pm 0.01$ & 69 & 4 \\
\hline
\end{tabular}


The cytotoxicity of the compound was determined towards three different cell lines using the MTT assay method. For comparison, the compound $[($ cym $) \mathrm{Ru}(\mathrm{en}) \mathrm{Cl}] \mathrm{Cl}$ (7) was also introduced in the cell line studies (Table 4 and Fig. 5). Cell lines used were Hct116 human colon carcinoma, H4IIE rat hepatoma and A2780 human ovarian carcinoma cells (cisplatin sensitive). The cytotoxicity values for these compounds fall in the range commonly observed for various $\mathrm{Ru}\left(\right.$ arene)-type complexes. ${ }^{[31,52,53]}$

As expected, the complexes coordinatively saturated $\mathbf{6 a}$ and $\mathbf{6 b}$ are not cytotoxic at concentrations up to $100 \mu \mathrm{M}$ after 24, 48 and 72 hours of incubation, respectively (Table 4). Compounds $\mathbf{5} \mathbf{a}$ and $\mathbf{5 b}$ containing $\kappa^{2} N, N$ bonded ligands show no toxicity in the cell lines used. The steric repulsion of the imidazolyl groups in $\mathbf{5 b}$ may hinder coordination to DNA bases. Additionally, the NH groups in 5a' point away from a possible binding site due to the ligand geometry. In complexes [(arene)Ru(en')X] with ethylene diammine derivatives (en') it has been shown that $\mathrm{NH}$ functionalities in the en' ligand are essential for efficient DNA binding. ${ }^{[20,54,55]}$

The compounds $\left[(p\right.$-cymene $\left.) \mathrm{Ru}(\mathbf{1 a}) \mathrm{Cl}_{2}\right]$ (4a) shows cytotoxicity towards $\mathrm{A} 2780$ sens and Hct116 cells in the $\mu \mathrm{M}$ range but not in H4IIE cells. The cytotoxicity is decreased upon introduction of a methyl group as $\left[(p\right.$-cymene $\left.) \mathrm{Ru}(\mathbf{1 b}) \mathrm{Cl}_{2}\right](\mathbf{4 b})$ shows only modest toxicities in the cell lines investigated. In general $\mathbf{4 a}$ is more cytotoxic then $\mathbf{4 b}$. As mentioned above, free $\mathrm{NH}$ functions as in $\left[(\right.$ arene $\left.) \mathrm{Ru}\left(\mathrm{en}^{\prime}\right) \mathrm{X}\right]$ should favour DNA binding. This is not a valid explanation here, as the melting temperatures for $\mathbf{4 a}$ and $\mathbf{4 b}$ are essentially the same.

Table 4. Cell viability tests after 24 and 72 hours of incubation, $\mathrm{IC}_{50}$ values given in $\mu \mathrm{M}$ (n.d. not determined).

\begin{tabular}{lcccccccc}
\hline Cell line & $\begin{array}{l}\text { Incubation } \\
\text { time }\end{array}$ & $\mathbf{4 a}$ & $\mathbf{4 b}$ & $\mathbf{5 a}$ & $\mathbf{5 a}$ & $\mathbf{5 b}$ & $\mathbf{6 a}$ & $\mathbf{6 b}$ \\
\hline A2780sens & $24 \mathrm{~h}$ & 83 & $>100$ & $>100$ & $>100$ & $>100$ & n.d. & n.d. \\
& $72 \mathrm{~h}$ & 38 & 95 & $>100$ & $>100$ & $>100$ & n.d. & n.d. \\
\hline Hct116 & $24 \mathrm{~h}$ & 66 & $>100$ & $>100$ & $>100$ & $>100$ & $>100$ & $>100$ \\
& $72 \mathrm{~h}$ & 58 & $>100$ & n.d. & n.d. & n.d. & $>100$ & $>100$ \\
\hline H4IIE & $24 \mathrm{~h}$ & $>100$ & $>100$ & $>100$ & $>100$ & $>100$ & $>100$ & $>100$ \\
& $72 \mathrm{~h}$ & $>100$ & $>100$ & 54 & $>100$ & $>100$ & $>100$ & $>100$
\end{tabular}


Although 5a and 4a both have the $\kappa P$ binding mode and therefore resemble RAPTA-type $\left[(\right.$ arene $) \mathrm{RuCl}_{2}($ pta $\left.)\right]$ complexes, $\mathbf{5 a}$ is almost non-toxic in the cell lines investigated within 24 of incubation. After 72 and 96 hours of incubation a selective toxicity of 5a towards H4IIE cells is found (Table 4 and Fig. 6). Reason for the decreased toxicity of compound 5a to $4 \mathbf{a}$ might be the hydrophobicity. The selective toxicity of 5a in H4IIE cells might be an effect of $5 \mathrm{a}$ in the cell cycle leading to delayed toxic effects. In addition it is well known, that RAPTtype complexes not only act as DNA binders. The poor correlation found here could also point towards a different mechanism, where proteins are favoured targets for the compounds. For corresponding complexes this has been shown by the groups of Messori and Davey. [29,56]

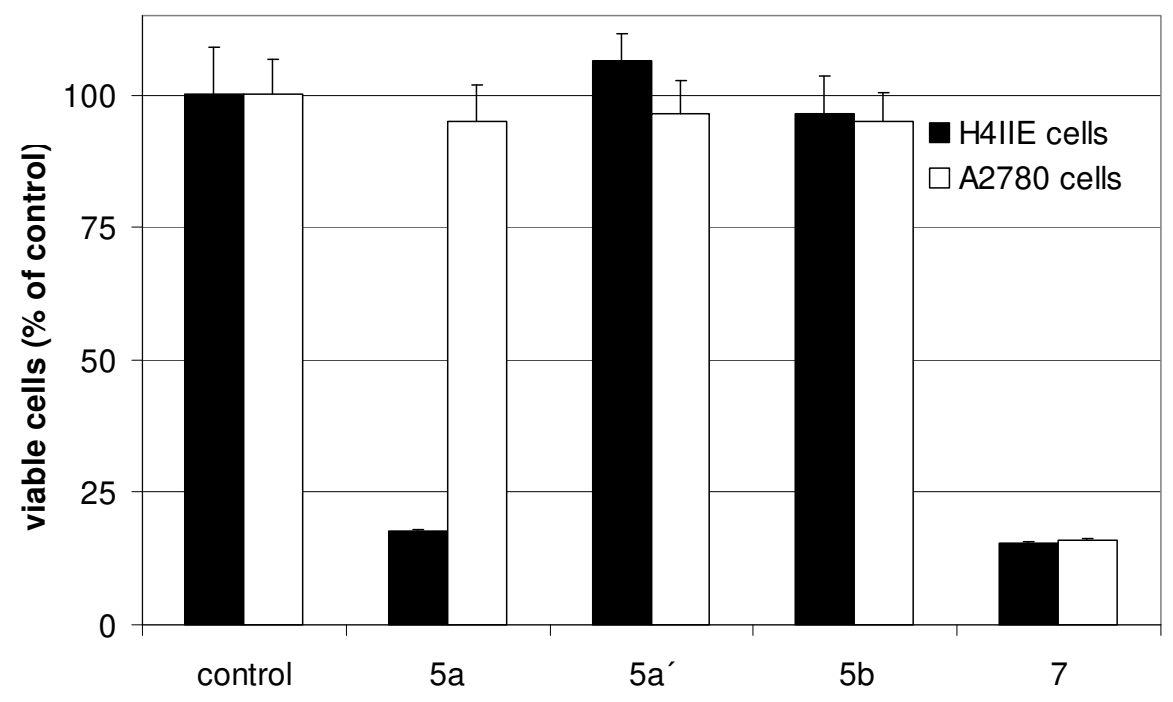

Fig. 5. Cytotoxic effects 5a, 5a', 5b and $\mathbf{7}$ in H4IIE and A2780 cells. H4IIE rat hepatoma and A2780 human ovarian carcinoma cells were incubated with $\mathbf{5 a}, \mathbf{5 \mathbf { a } ^ { \prime }}, \mathbf{5 b}$ or $\mathbf{7}(100 \mu \mathrm{M})$ for $72 \mathrm{~h}$, then MTT reduction as a marker of cell viability was measured (absorbance at $560 \mathrm{~nm}$ ). Results are expressed as viable cells in percent of control value $\pm \operatorname{SD}$. $(n=3, *$ : $p<0,05$ vs. corresponding DMSO control). 


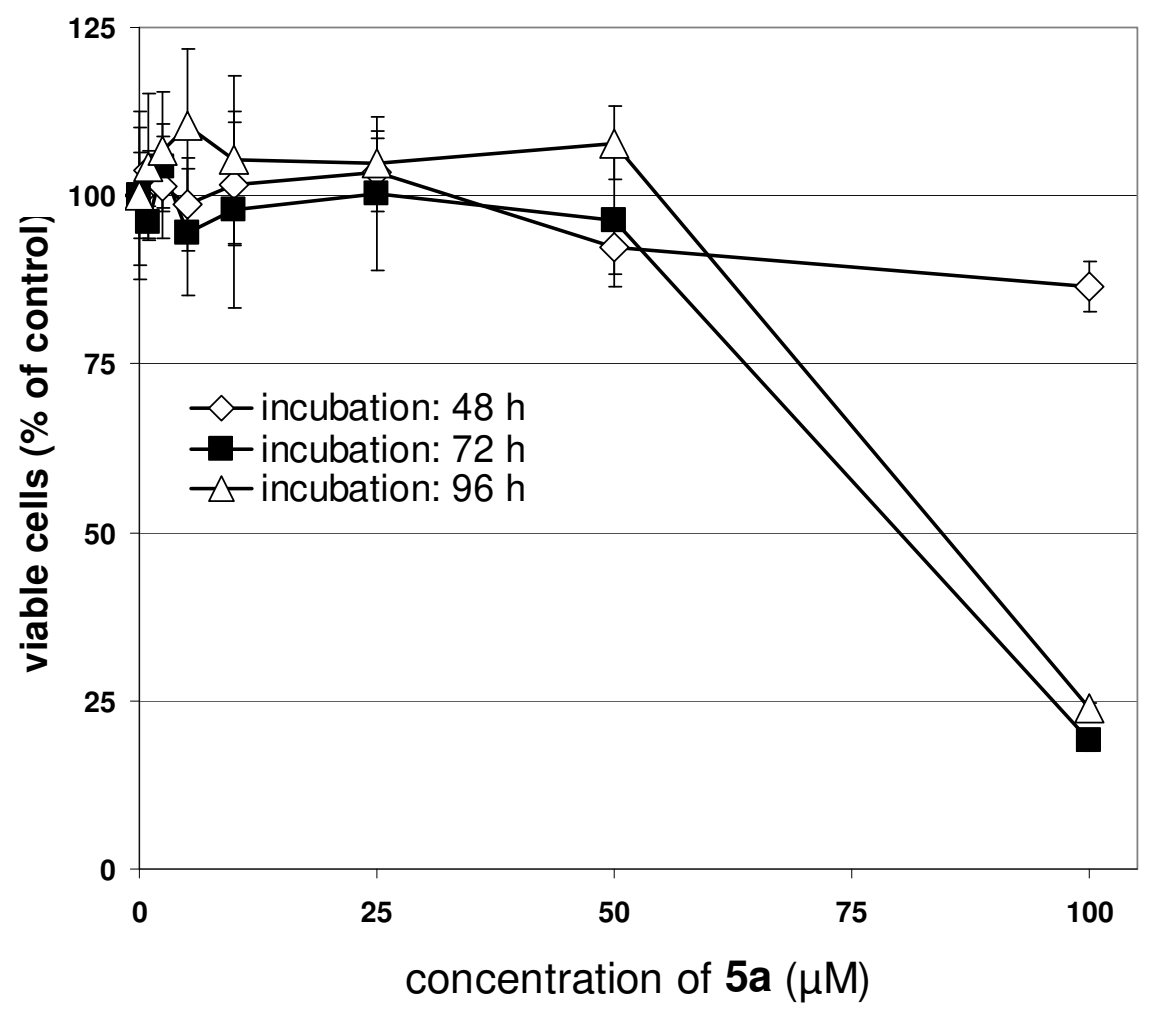

Fig. 6. Cytotoxic effects of 5a in H4IIE. H4IIE rat hepatoma cells were incubated with different concentrations of 5a for 48, 72 and $96 \mathrm{~h}$, then MTT reduction as a marker of cell viability was measured (absorbance at $560 \mathrm{~nm}$ ). Results are expressed as viable cells in percent of control value $\pm \mathrm{SD}$. $(n=3, *: \mathrm{p}<0,05$ vs. corresponding DMSO control).

\section{Conclusion}

We prepared a series of ruthenium(II) arene complexes with ambidentate PN ligands. All compounds displaying a chelating $\kappa^{2} N, N$ or $\kappa^{3} N, N, N$ coordination mode show no cytotoxicity towards the used Hct116, H4IIE and A2780 cell lines. The most lipophilic complex 4a show the highest cytotoxicity within the series of compounds, with $\mathrm{IC}_{50}$ values in the micromolar range. Complex 5a, in which ligand $\mathbf{2 a}$ is bound in the $\kappa P$ mode, shows a selective cytotoxicity towards H4IIE cells after 72 hours. In contrast complex 5a', in which ligand 2a is bound in the $\kappa^{2} N, N$ mode, shows no cytotoxic effects in the cell lines investigated.

\section{References}

[1] O. Rixe, W. Ortuzar, M. Alvarez, R. Parker, Biochem. Pharm. 1996, 52, 18551851865.

[2] B. Spingler, D. Whittington, S. J. Lippard, Inorg. Chem. 2001, 40, 5596-5602. 
[3] A. V. Klein, T. W. Hambley, Chem. Rev. 2009, 109, 4911-4920.

[4] R. Ingo Ott, Pharm. unserer Zeit 2006, 35, 124-133.

[5] P. Abada, S. B. Howell, Met. Based Drugs 2010, Article ID 317581.

[6] E. Alessio, Ed., Bioinorganic Medicinal Chemistry, Wiley-VCH, Weinheim, 2011.

[7] M. Gielen, E. R. T. Tiekink, Eds., Metallotherapeutic Drugs and Metal-Based Diagnostic Agents: the Use of Metals in Medicine, John Wiley \& Sons, Chichester, 2005.

[8] P. C. Bruijnincx, P. J. Sadler, Curr. Opin. Chem. Biol. 2008, 12, 197-206.

[9] A. Bergamo, G. Sava, Dalton Trans. 2011, 40, 7817-7823.

[10] E. S. Antonarakis, A. Emadi, Cancer Chemother. Pharmacol. 2010, 66, 1-9.

[11] S. H. van Rijt, P. J. Sadler, Drug Discovery Today 2009, 14, 1089-1097.

[12] G. Sava, Met. Based Drugs 2007, Article ID 16260.

[13] G. Jaouen, Ed., Bioorganometallics. Biomolecules, Labeling, Medicine., Wiley VCH, 2006.

[14] C. Vock, C. Scolaro, A. Phillips, R. Scopelliti, G. Sava, P. J. Dyson, J. Med. Chem. 2006, 49, 5552-5561.

[15] W. Han Ang, P. J. Dyson, Eur. J. Inorg. Chem. 2006, 2006, 4003-4018.

[16] R. Aird, J. Cummings, A. Ritchie, M. Muir, R. Morris, H. Chen, P. J. Sadler, D. Jodrell, Br. J. Cancer 2002, 86, 1652-1657.

[17] C. A. Smith, A. J. Sutherland-Smith, F. Kratz, E. Baker, B. K. Keppler, J. Biol. Inorg. Chem. 1996, 1, 424-431.

[18] J. M. Rademaker-Lakhai, D. van den Bongard, D. Pluim, J. H. Beijnen, J. H. M. Schellens, Clin. Cancer Res. 2004, 10, 3717-3727.

[19] S. Zorzet, A. Bergamo, M. Cocchietto, A. Sorc, B. Gava, E. Alessio, E. Iengo, G. Sava, J. Pharmacol. Exp. Ther. 2000, 295, 927-933.

[20] H. Chen, J. A. Parkinson, S. Parsons, R. A. Coxall, R. O. Gould, P. J. Sadler, J. Am. Chem. Soc. 2002, 124, 3064-3082.

[21] H. Chen, J. A. Parkinson, O. Nováková, J. Bella, F. Wang, A. Dawson, R. Gould, S. Parsons, V. Brabec, P. J. Sadler, Proc. Natl. Acad. Sci. USA 2003, 100, 14623-14628.

[22] H. Chen, J. A. Parkinson, R. E. Morris, P. J. Sadler, J. Am. Chem. Soc. 2003, 125 , 173-186.

[23] A. Bergamo, A. Masi, P. J. Dyson, G. Sava, Int. J. Oncol. 2008, 33, 1281-12811289.

[24] S. Chatterjee, S. Kundu, A. Bhattacharyya, C. G. Hartinger, P. J. Dyson, J. Biol. Inorg. Chem. 2008, 13, 1149-1155.

[25] F. Wang, H. Chen, S. Parsons, I. D. H. Oswald, J. E. Davidson, P. J. Sadler, Chem.Eur. J. 2003, 9, 5810-5820.

[26] C. Scolaro, A. Bergamo, L. Brescacin, R. Delfino, J. Med. Chem. 2005, 48, 41-4171.

[27] A. Casini, F. Edafe, M. Erlandsson, L. Gonsalvi, A. Ciancetta, N. Re, A. Ienco, L. Messori, M. Peruzzini, P. J. Dyson, Dalton Trans. 2010, 1-16.

[28] X. Sun, C.-N. Tsang, H. Sun, Metallomics 2009, 1, 25-31.

[29] A. Casini, C. Gabbiani, F. Sorrentino, M. P. Rigobello, A. Bindoli, T. J. Geldbach, A. Marrone, N. Re, C. G. Hartinger, P. J. Dyson, et al., J. Med. Chem. 2008, 51, 67736781.

[30] C. Wetzel, P. C. Kunz, M. U. Kassack, A. Hamacher, P. Böhler, W. Wätjen, I. Ott, R. Rubbiani, B. Spingler, Dalton Trans. 2011, 40, 9212-9220.

[31] A. L. Noffke, undefined author, M. Bongartz, undefined author, W. Wätjen, P. Böhler, undefined author, B. Spingler, P. C. Kunz, J. Organomet. Chem. 2011, 696, 1096-1101.

[32] P. C. Kunz, M. U. Kassack, A. Hamacher, B. Spingler, Dalton Trans. 2009, 77417747.

[33] P. C. Kunz, I. Thiel, A. L. Noffke, G. J. Reiß, F. Mohr, B. Spingler, J. Organomet. 
Chem. 2012, 697, 33-40.

[34] C. Wetzel, P. C. Kunz, I. Thiel, B. Spingler, Inorg. Chem. 2011, 50, 7863-7870.

[35] A. Caballero, F. Jalon, B. Manzano, G. Espino, Organometallics 2004, 23, 5694 5706.

[36] S. Moore, G. M. Whitesides, J. Org. Chem. 1982, 47, 1489-1493.

[37] N. Curtis, R. Brown, J. Org. Chem. 1980, 45, 4038-4040.

[38] H.-Q. Liu, T.-C. Cheung, S.-M. Peng, C.-M. Che, J. Chem. Soc., Chem. Commun. 1995, 1787-1788.

[39] T. Mosmann, J. Immunol. Methods 1983, 65, 55-63.

[40] G. M. Sheldrick, Acta Crystallographica Section E: Structure Reports Online 2008, A64, 112-122.

[41] Oxford Diffraction Ltd, CrysAlisPro Software System, 2007.

[42] A. Altomare, M. C. Burla, M. Camalli, G. L. Cascarano, C. Giacovazzo, A. Guagliardi, A. G. G. Moliterni, G. Polidori, Riccardo Spagna, J. Appl. Cryst. 1999, 32, 115-119.

[43] A. L. L. Spek, J. Appl. Cryst. 2003, 36, 7-13.

[44] P. C. Kunz, M. Börgardts, F. Mohr, Inorg. Chim. Acta 2012, 380, 392-398.

[45] P. C. Kunz, W. Huber, A. Rojas, U. Schatzschneider, B. Spingler, Eur. J. Inorg. Chem. 2009, 5358-5366.

[46] P. C. Kunz, G. J. Reiß, W. Frank, W. Kläui, Eur. J. Inorg. Chem. 2003, 3945-3951.

[47] M. R. J. Elsegood, M. B. Smith, N. M. Sanchez-Ballester, Acta Crystallographica Section E: Structure Reports Online 2006, E62, 2838-2840.

[48] C. Allardyce, P. J. Dyson, D. Ellis, S. Heath, Chem. Commun. 2001, 1396-1397.

[49] I. Moldes, E. de la Encarnación, J. Ros, Á. Alvarez-Larena, J. F. Piniella, J. Organomet. Chem. 1998, 566, 165-174.

[50] P. Kumar, A. K. Singh, R. Pandey, P.-Z. Li, S. K. Singh, Q. Xu, D. S. Pandey, J. Organomet. Chem. 2010, 695, 2205-2212.

[51] F. Marchetti, C. Pettinari, R. Pettinari, A. Cerquetella, C. Di Nicola, A. Macchioni, D. Zuccaccia, M. Monari, F. Piccinelli, Inorg. Chem. 2008, 47, 11593-11603.

[52] D. J. M. Snelders, A. Casini, F. Edafe, G. van Koten, R. J. M. K. Gebbink, P. J. Dyson, J. Organomet. Chem. 2011, 696, 1108-1116.

[53] A. K. Renfrew, A. D. Phillips, A. E. Egger, C. G. Hartinger, S. S. Bosquain, A. A. Nazarov, B. K. Keppler, L. Gonsalvi, M. Peruzzini, P. J. Dyson, Organometallics 2009, 28, 1165-1172.

[54] S. Das, S. Sinha, R. Britto, K. Somasundaram, A. G. Samuelson, J. Inorg. Biochem. 2010, 104, 93-104.

[55] A. Habtemariam, M. Melchart, R. Fernández, S. Parsons, I. D. H. Oswald, A. Parkin, F. P. A. Fabbiani, J. E. Davidson, A. Dawson, R. E. Aird, et al., J. Med. Chem. 2006, 49, 6858-6868.

[56] B. Wu, M. S. Ong, M. Groessl, Z. Adhireksan, C. G. Hartinger, P. J. Dyson, C. A. Davey, Chem.-Eur. J. 2011, 17, 3562-3566. 
Electronic Supplementary Information for

\section{Methyl Groups Make the Difference - Cytotoxicity of Ruthenium(II) Piano-Stool Complexes with PN Ligands}

Wilhelm Huber, ${ }^{b}$ Philip Bröhler, ${ }^{c}$ Wim Wätjen, ${ }^{c}$ Walter Frank ${ }^{b, t}$ and Bernhard Spingler ${ }^{d, t}$ and Peter C. Kunz, ${ }^{a, b^{*}}$

a Institut für Pharmazeutische und Medizinische Chemie, Heinrich-Heine-Universität, Universitätsstr. 1, D-40225 Düsseldorf, Tel.: +49 211 81-12873, Fax: +49 211 81-12287, Email: peter.kunz@uni-duesseldorf.de.

$b$ Institut für Anorganische Chemie und Strukturchemie, Heinrich-Heine-Universität, Universitätsstr. 1, D-40225 Düsseldorf.

c Universitätsklinikum Düsseldorf, Institut für Toxikologie, Heinrich-Heine-Universität, Universitätsstr. 1, D-40225 Düsseldorf.

$d$ University of Zürich, Institute of Inorganic Chemistry, Winterthurerstrasse 190, CH-8057 Zürich.

$\neq \mathrm{X}$-ray structure analysis 


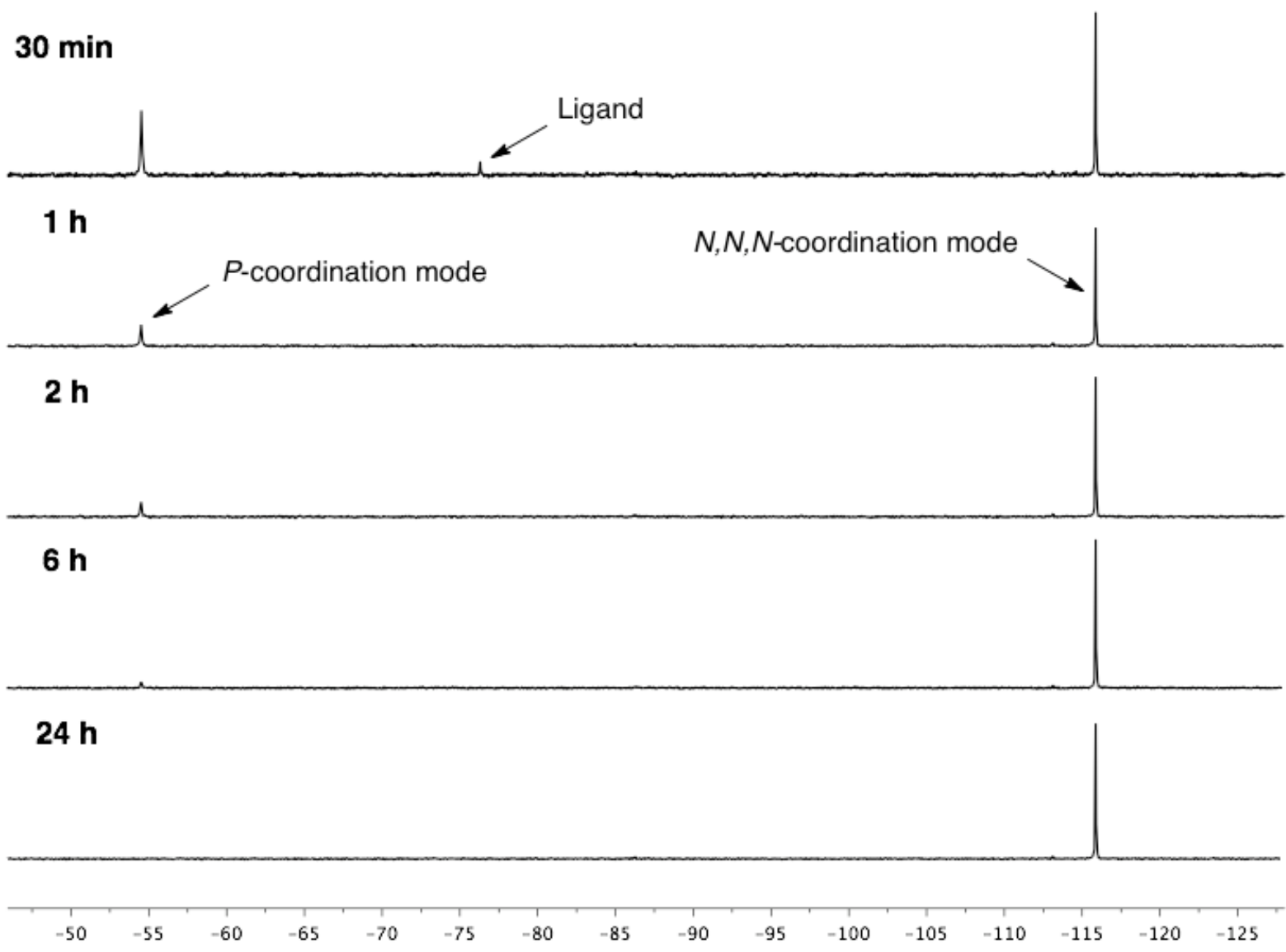

Fig ESI1. ${ }^{31} \mathrm{P}\left\{{ }^{1} \mathrm{H}\right\}-\mathrm{NMR}$ spectra taken from the reaction mixture of $\left[\left\{(\mathrm{cym}) \mathrm{RuCl}_{2}\right\}_{2}\right]$ and $\mathbf{3 b}$ in $\mathrm{MeCN}$. 


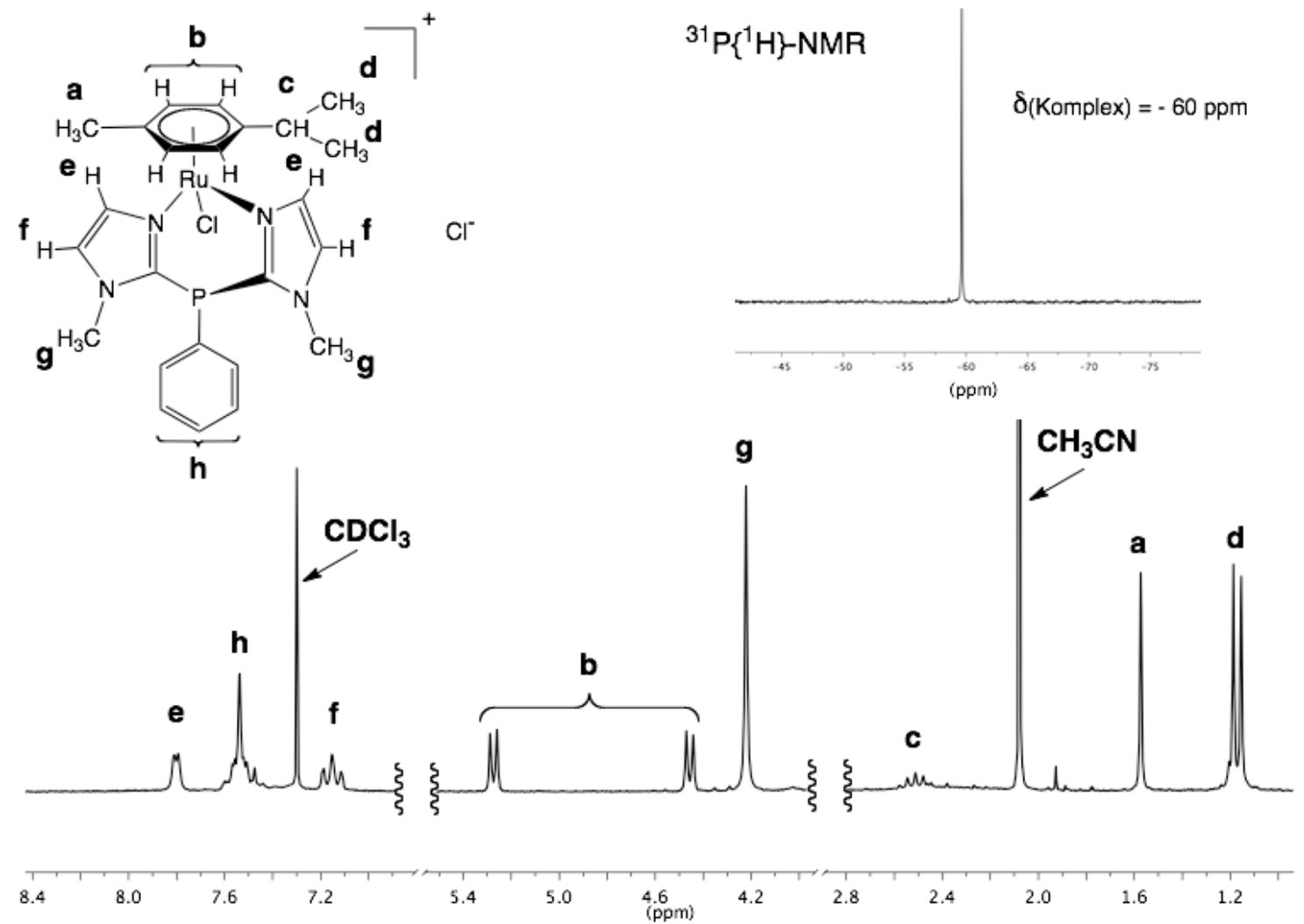

Fig. ESI2. Excerpts of the ${ }^{1} \mathrm{H}$ und ${ }^{31} \mathrm{P}\left\{{ }^{1} \mathrm{H}\right\}$ NMR spectra of $\left[(\operatorname{cym}) \mathrm{Ru}\left(\kappa^{2} N, N-\mathbf{2 b}\right) \mathrm{Cl}\right] \mathrm{Cl}(\mathbf{5 b})$ in $\mathrm{CDCl}_{3}$. 

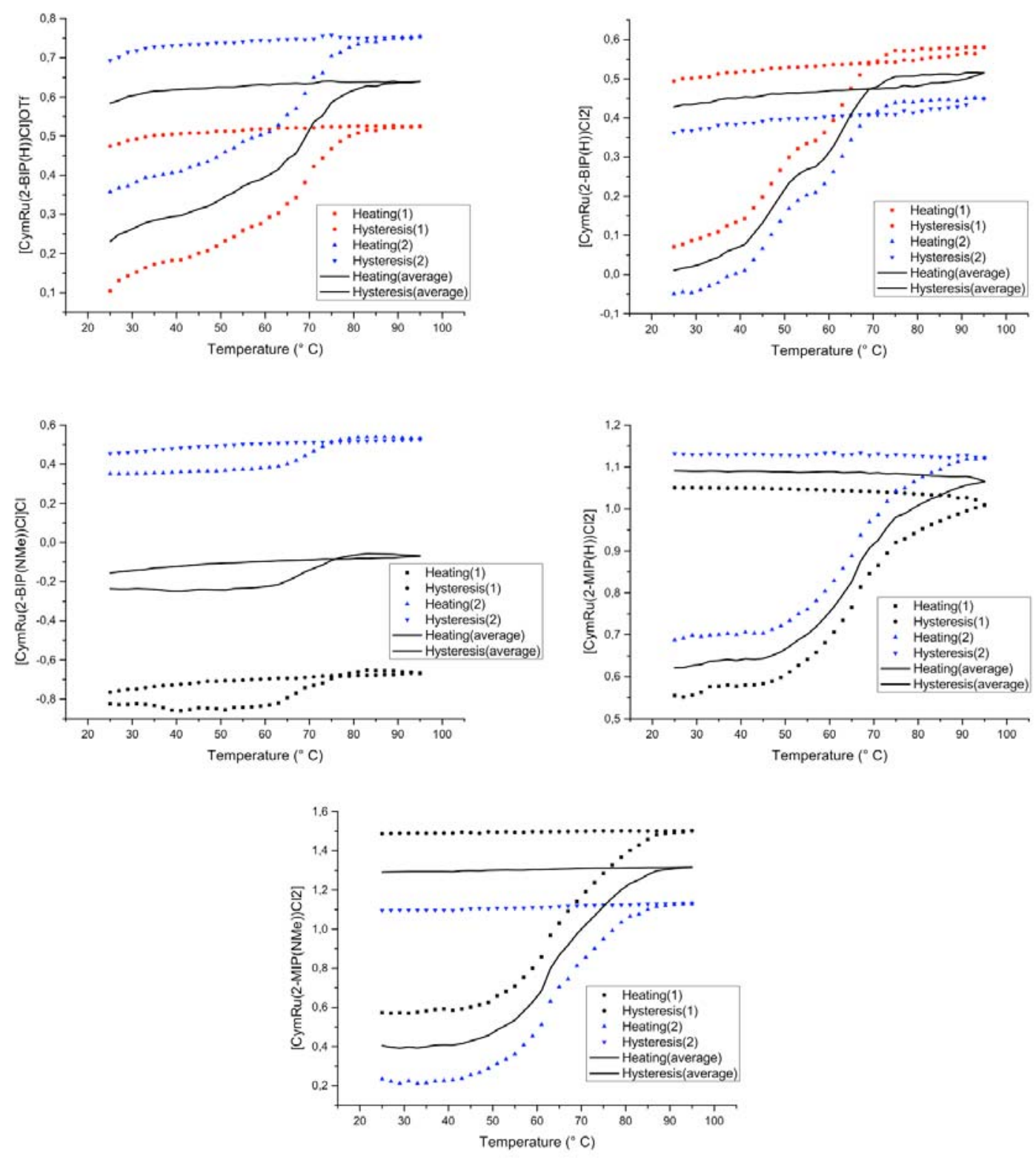

Fig. ESI3. DNA melting curves in the presence of complexes $\mathbf{4 a - 5} \mathbf{b}$. Thermal denaturation temperatures $\left(T_{\mathrm{M}}\right)$ were determined using the Origin ${ }^{\circledR}$ software package (Boltzmann sigmoidal curve fitting). 